\title{
Growth and population structure of Paracentrotus lividus (Echinodermata: Echinoidea) in two contrasting habitats
}

\author{
X. Turon, G. Giribet, S. López, C. Palacín \\ Department of Animal Biology (Invertebrates), Faculty of Biology, University of Barcelona, Avinguda Diagonal, 645, \\ E-08028 Barcelona, Spain
}

\begin{abstract}
Two populations of Paracentrotus lividus (Lamarck) (Echinodermata: Echinoidea) from the Northwestern Mediterranean were compared to ascertain the plasticity and adaptive value of certain biological parameters. These populations were found in habitats which differed in terms of stability of environmental parameters and availability of food. The density was higher and more fluctuating in the unstable community. Sigmoidal growth functions were fitted from plate ring analysis, and reflected a higher growth rate in the stable community, resulting in higher mean diameters at equal age. The maximal growth rate was attained in the unstable community at an earlier age than in the stable one. Size-frequency analyses reflected drastic month-to-month changes in population structure in the unstable community, in which the smaller size classes were almost absent. In contrast, at the stable site the distribution was much more uniform through tıme, and featured a polymodal shape consistent with the development of several annual cohorts. The smaller size classes were the most abundant. It is suggested that different dynamics underhe both populations, the one at the unstable site being driven primarily by episodic storms, which cause high mortalities but carry new individuals to the site. The stable community relies instead on an annual settlement and features a lower and more predictable mortality which allows for the development of a well-structured population.
\end{abstract}

KEY WORDS: Population dynamics - Growth · Gompertz function Echinoidea P Paracentrotus

\section{INTRODUCTION}

The sea urchin Paracentrotus lividus (Lamarck) (Echinodermata. Echinoidea) is an Atlanto-Mediterranean form found in great numbers in the littoral zone, especially in the sublittoral level down to $20 \mathrm{~m}$. Many aspects of its biology and population parameters are poorly known, although it is an edible species of commercial interest.

In this study, the main life-history parameters of 2 populations of this species were investigated. These 2 populations were found in ecological situations which differed in terms of stability of environmental parameters and food availability. The aim of this study was to describe the biology and population dynamics of this species and to ascertain the plasticity and adaptive value of different biological parameters. In another paper, Lozano et al. (1995, this issue) reported the main results concerning reproductive and feeding cycles, as well as timing and intensity of recruitment, of the populations studied. The present paper focuses on the density fluctuations, growth and structure of the populations in these communities. Both populations seemed to be well established in the sense that a fair number of sea urchins at both sites have been observed year round, not only during the study period, but also in the many years of marine biology research in diverse fields conducted at these localities. Our hypothesis in this paper was that these dense, apparently well-established populations which belong to such diverse habitats, must develop following differing processes and, therefore, feature different structure and dynamics. Knowledge of these dynamics is, on the other hand, a necessary prerequisite for a management of this resource. It has long been recognized that echinoid growth rates are highly sensitive to factors such as food availability and hydrodynamism (Ebert 1968, Himmelman 1986). Fewer data, however, are available on habitat influences in population structure and other biological parameters (Himmelman 1986, Byrne 1990, King et al. 1994). 
Several techniques have been employed for the study of growth and population structure in echinoids: the study of size-frequency distributions, the analysis of growth rings in the test, mark-recapture techniques (usually with tetracycline labelling, first used by Kobayashi \& Taki 1969), and monitoring of animais in enclosures. Each has its own limitations, and a combination of several of them is more likely to produce reliable results. In this study, we have combined data from growth marks in the plates with results from the changes in size-frequency distributions through time to obtain data on the growth and dynamics of the populations analyzed

\section{MATERIAL AND METHODS}

Sampling sites. The study was performed on specimens from 2 localities, Tossa de $\operatorname{Mar}\left(41^{\circ} 43.2^{\prime} \mathrm{N}\right.$, $\left.2^{\circ} 56.4^{\prime} \mathrm{E}\right)$ and Cubelles $\left(41^{\circ} 12.0^{\prime} \mathrm{N}, 1^{\circ} 40.8^{\prime} \mathrm{E}\right)$, both on the northeast coast of Spain (Northwestern Mediterranean). A map of the area and descriptions of each zone are presented in Lozano et al. (1995). Essentially, the site at Tossa de Mar is representative of a wellestablished, stable (with respect to most physical parameters) community in rocky vertical walls between 3 and $10 \mathrm{~m}$ in depth, with high coverage of diverse fleshy algal species. This will be referred to hereafter as the stable community. The site at Cubelles was an open, shallow $(0.5 \mathrm{~m}$ in depth) beach with small-tomedium sized boulders on which a poorly developed community of small coralline algae was found. This site is referred to as the unstable community.

Unless otherwise stated, the samplings for the different parameters were carried out approximately every 2 wk from June 1992 to July 1993 at Tossa, and from July 1992 to August 1993 at Cubelles. Results are presented as monthly means to reduce stochastic variation.

Density fluctuations. Fixed transects were censused at both localities to assess density fluctuations of the populations. At Tossa de Mar, 3 transects $25 \mathrm{~m}$ long $\times 1 \mathrm{~m}$ wide were placed horizontally at a depth of 3,6 and $9 \mathrm{~m}$ in a nearly vertical wall. At Cubelles, a $25 \times 1 \mathrm{~m}$ transect was deployed, perpendicular to the coast line, running from 0.3 to $0.7 \mathrm{~m}$ in depth. The specimens present in these transects were counted at approximately the same hour (13:00 h) during daylight on each sampling date.

Growth ring measurements. Samples of 20 individuals of Paracentrotus lividus of all sizes were taken every 2 wk at both localities. The samples were fixed and preserved in formalin. Growth rings were studied in 509 individuals from Tossa de Mar and 537 from Cubelles [these were the same specimens as those used in Lozano et al. (1995) for the study of biological cycles].
The maximum diameter of the individuals was measured to the nearest $0.1 \mathrm{~mm}$ in the laboratory. The body was then oven dried at $120^{\circ} \mathrm{C}$ for $48 \mathrm{~h}$ and weighed. The test was cleaned of spines and an interambulacral series of plates was dissected and used to count growth rings (Jensen 1969, Allain 1978, Azzolina 1988, Gage 1991). Within one coronal series, the larger plates corresponding to the zone of the ambitus were the most suitable for ring counting, since in the older ones (near the peristomial membrane) the distal bands were hardly distinct and resorption phenomena were present (Smith 1980). Interambulacral series were used because they were free of podia orifices. The observation of the rings was easy after drying, and the preparation procedure of Jensen (1969) was not necessary. Rings were visualized simply by immersing the plates in xylene and observing them under a stereomicroscope. The number of translucent rings (dark in reflected light) was counted. They were narrower than the opaque ones and easier to count.

Statistical analyses were performed on the size data using 2-way ANOVA for unbalanced designs. The Tukey test (Zar 1984) was used for multiple comparisons. Prior to performing parametric tests, the assumptions of normality and homoscedasticity were tested by Kolmogorov-Smirnov and Bartlett tests, respectively. The SYSTAT package (v. 5.0) was used for the analyses.

The data on size and number of growth rings were transformed to size-at-age under the assumptions of an annual formation of the rings (see 'Discussion') and of 1 main settlement episode per year (Lozano et al. 1995). After trying different models (see 'Discussion'), the Gompertz equation was used to fit a growth function to these measurements. It has the form (we used the same formulation as Cellario \& Fénaux 1990):

$$
L_{t}=L_{\infty 0} \mathrm{e}^{-b \mathrm{e}^{-k t}}
$$

where $L_{l}$ is the test diameter at time $t_{1} L_{\infty}$ is the maximum test diameter, the scale parameter $b=\ln L_{c o} / L_{0}$ where $L_{0}$ is the diameter at $t=0$ (settlement on bottom), and $k$ is a constant of the model.

The means of the sizes of each age-class were used to fit the growth function. Parameter estimation was performed using a nonlinear procedure (NONLIN module of the SYSTAT program with the default Quasi-Newton minimization algorithm).

In order to ascertain the timing of ring formation, a labelling experiment was started in March 1994 in the stable community. A total of 272 individuals of all sizes were collected, taken to the shore in $20 \mathrm{l}$ jars, and a $1 \%$ aqueous solution of tetracycline hydrochloride (Boehringer Mannheim) was injected through the peristome. The sea urchins were then returned to their 
natural habitat. The dose was set at $0.1 \mathrm{ml}$ per $10 \mathrm{~g}$ wet body weight, following Gage (1991). We measured the diameters of the sea urchins to estimate body weight. after the corresponding regression figures calculated with data of the specimens collected for biological cycles. The time of labelling was visible in the test of the sea urchins as a fluorescent tag of tetracycline incorporated into the structure of the test and visible under ultraviolet light. This experiment is planned to continue for $2 \mathrm{yr}$, but we report here the results concerning some individuals 47 were collected, 29 featured the tetracycline tag) that were recovered from the same place at the end of July 1994. The nature of the outermost band in the plates was also recorded at Tossa throughout the year as indirect evidence of the pattern of ring formation.

Size-frequency distributions. For size-frequency analyses, 1 fixed transect was set at each locality at the same site and was perpendicular to the transects used for density estimations. At Tossa the transect was $6 \mathrm{~m}$ long $\times 1 \mathrm{~m}$ wide and was placed between 4 and $8 \mathrm{~m}$ in depth following a nearly vertical crevice in the wall. At Cubelles, a $15 \times 1 \mathrm{~m}$ line was placed parallel to the coast at $0.5 \mathrm{~m}$ depth.

All the specimens in these transects were measured (maximum diameter without spines) once a month. Care was taken to examine all cryptic spaces such as undersurfaces of boulders or small crevices. Most of the specimens were satisfactorily measured using sharpened-point calipers without causing harm to the urchins. A slight overestimation of the diameter was unavoidable, due to the underwater working conditions and the presence of spines, which made the use of calipers difficult. The measurements were made at approximately the same hour (13:00 h) during daylight.

This part of the study was performed from January 1993 to January 1994 at Tossa de Mar, and from December 1992 to August 1993 at Cubelles. After this date, the construction of a nearby jetty altered the zone of the transect and we thought it advisable to discontinue the study at Cubelles.

Size-frequency histograms were constructed, and a moving average 3 points wide was applied to filter the noise from the data. Modal analyses were performed to identify cohorts in the size distributions using Battacharya's method (Battacharya 1967), with the aid of the ELEFAN package (ICLARM software, Pauly \& David 1981).

\section{RESULTS}

\section{Density fluctuations}

Fig. 1 shows the temporal trend of the number of ind. $\mathrm{m}^{-2}$ censused in the 3 fixed transects of $25 \mathrm{~m}^{2}$ at Tossa and in the single transect at Cubelles. At Tossa the densities fluctuated between 2 and 11 ind. $\mathrm{m}^{-2}$, with a trend of decreasing numbers with depth. The global minima were found in September and May, although no sharp variations were detected from one month to the next.

At Cubelles, the single transect surveyed featured mean densities higher than those at Tossa (from 3 to 31 ind. $\mathrm{m}^{-2}$ ), and some abrupt variations were detected, especially at the end of summer in 1992 (from 14 August to 2 September, the population dropped from 765 to 92 individuals in the $25 \mathrm{~m}^{2}$ ), coinciding with strong storms and easterly winds in the area.

\section{Growth ring measurements}

Growth rings were successfully counted in 463 individuals of Tossa (90.96\% of the collected specimens) and 492 individuals at Cubelles (91.62\%). Most of the specimens in which the reading was not possible, due to merging of rings, were large-sized forms from both localities.

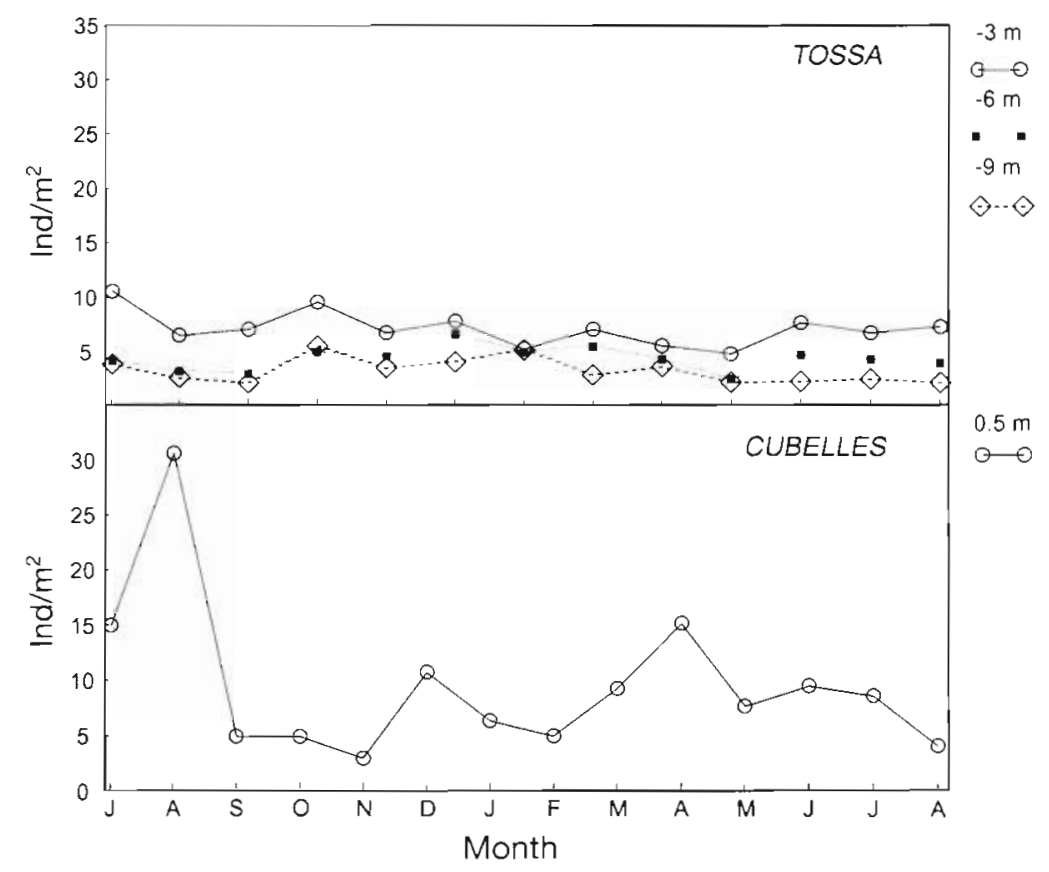

Fig. 1. Paracentrotus lividus. Temporal trend of the densities (ind. $\mathrm{m}^{-2}$ ) in the 3 fixed transects at Tossa and the single fixed transect at Cubelles on the northeast coast of Spain 

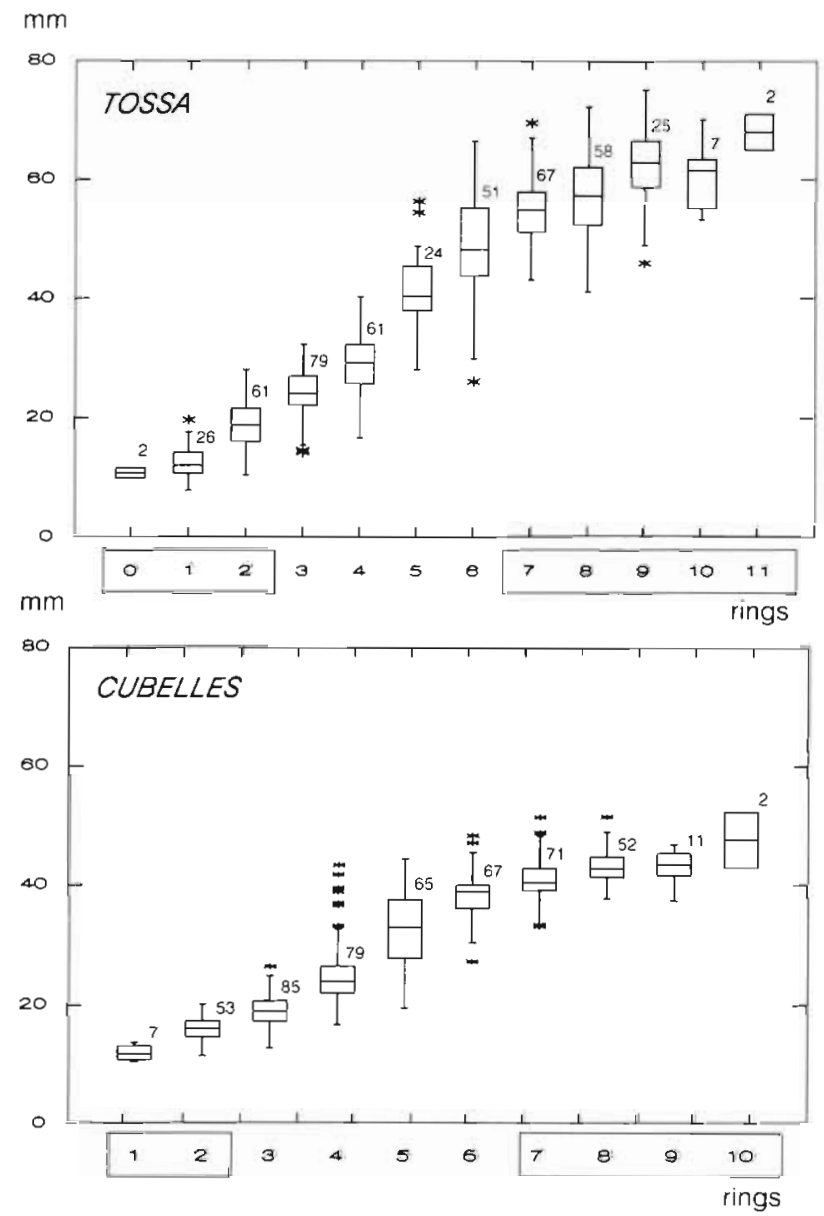

Fig. 2. Paracentrotus lividus. Box plots of the diameters of individuals from both localities as a function of the number of translucent rings in the plates of the interambulacral series. Horizontal lines within the boxes are the medians. The upper and lower limits of the boxes indicate the first and third quartiles, respectively. The vertical lines reach the highest (upper line) and lowest (lower line) values within 1.5 times the interquartile distance from the limits of the boxes. Values outside these limits are plotted with asterisks. Numbers of specimens measured in each ring class are indicated. The rectangles in the abcissa indicate ring classes whose mean diameters proved not significantly different in a Tukey test (see 'Results: growth ring measurements')

Fig. 2 displays the median and dispersion of the measures of test diameter against number of growth rings at both localities in the form of box plots (McGill et al. 1978). A 2-way ANOVA with locality and number of rings as factors was performed on the diameter values (ring classes 0 and 11 at Tossa excluded). Both factors proved highly significant (locality: F-ratio $=$ 266.67, df $=1,931, p<0.001$; ring number: F-ratio $=$ $681.617, \mathrm{df}=9,931, \mathrm{p}<0.001)$, as was also the interaction term $(F$-ratio $=22.038, \mathrm{df}=9,931, \mathrm{p}<0.001)$. In the presence of a significant interaction term, we analysed each factor at fixed levels of the other (Underwood
1981). Tukey tests between localities (for a fixed number of rings) showed that the sea urchins from the stable community had significantly larger diameters for all ring classes, except for the forms with a single growth ring. Tukey tests among ring classes (locality factor fixed) revealed that the smaller (up to 2 rings) and larger (from 7 onwards) ring classes were not significantly different within each locality (Fig. 2). This provided evidence of a sigmoid shape of the growth function, with asymptotic left and right legs.

The fitting of a growth function to ring data implies, besides accepting an annual pattern of formation of these marks (see below), the estimation of the time between settlement, formation of the first ring, and time of capture (Sime \& Cranmer 1985). We assume here that the main settlement of this species takes place in the beginning of summer (Lozano et al. 1995), and that the formation of the first opaque growth band (the nucleus region, formed during the first months, was not considered) takes place during the period of active growth in the next spring (see below), followed by the formation of the first translucent ring counted here. Therefore, an urchin with 1 translucent ring was between 1 year old (if captured at the beginning the formation of this translucent ring after the spring following the year of settlement) and 2 years old (at the end of the formation of the second opaque ring). In general, as we pooled measures from sea urchins collected year round, we expected that, on average, the sea urchins had an age (in years) $=N_{\text {rings }}+0.5$. This value has been adopted to translate data on number of translucent rings to age in years. Fig. 3 represents the fitted Gompertz function against age. The means of the diameters of the different ring classes are also depicted. The parameters of the function at Tossa were $L_{\infty}=77.451, b=2.645, k=0.252$, and the residual sum of squares (RSS) of the corresponding regression analysis was 55.59. At Cubelles the figures were $L_{\infty}=53.67, b=2.524, k=0.287$ and RSS $=21.444$.

Fig. 4 shows the trend of the growth rates with age. obtained from the derivative of the Gompertz function. The maximal growth rate was higher in the stable community (maximum of $7.7 \mathrm{~mm} \mathrm{yr}^{-1}$ ), and was reached at $4.78 \mathrm{yr}$. The highest rate at Cubelles (5.8 $\mathrm{mm} \mathrm{yr}^{-1}$ ) was found at $4.17 \mathrm{yr}$.

The results of the examination of the marginal ring in sea urchins from Tossa are presented in Fig. 5. The percentage of specimens in which the marginal band was an opaque ring was higher from March to June 1993, with maxima near $80 \%$ in May and June. The minimum was found in July 1993 (21\%). This indicated that the growth period was concentrated in spring, although actively growing individuals were found year round. The period of low growth leading to the formation of a translucent ring could be somewhat 


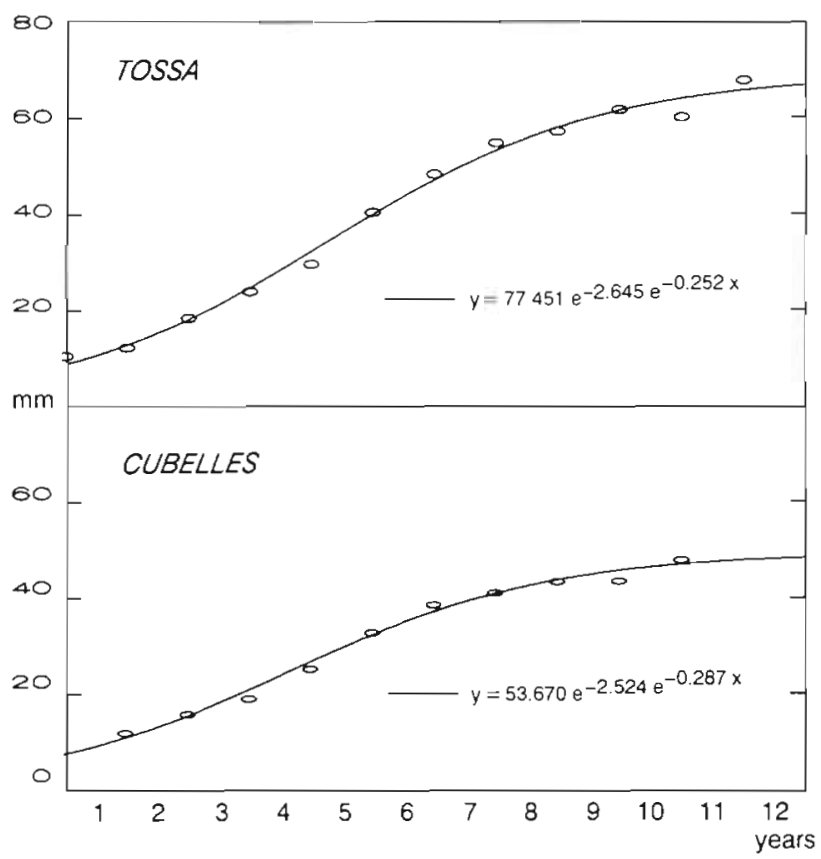

Fig. 3. Paracentrotus lividus. Gompertz's models fitted to the data of diameters at age inferred from the diameters of the ring classes (the means of the latter are depicted at its proposed age position $=$ number of rings +0.5 )

variable between individuals, but seemed to be concentrated during the gonad building phase (Lozano et al. 1995).

As for the individuals labelled with tetracycline in March 1994 and recaptured at the end of July 1994, in 2 of the 29 specimens the tetracycline tag formed a poorly defined band at the very margin of the plates and these were discarded (the injection could have damaged some organs and the sea urchins featured little or no growth during the intervening period). The distance between the tetracycline mark and the margin of the coronal plates in the other 27 specimens was $0.359 \pm 0.179 \mathrm{~mm}$ (mean \pm standard deviation, medsured on the largest plates of the coronal series, which, although they do not feature the highest growth, were the ones used for ring counting in this study). In all except 5 sea urchins the tetracycline mark was found within a narrow translucent ring. Of the 5 remaining specimens, in 2 of them the mark was placed slightly before (i.e. closer to the nucleus) this ring, and in the other 3 slightly after (closer to the margin) it. An opaque band always appeared between the translucent ring and the margin of the plate, which featured the beginning of another translucent ring in most $(28$ out of 29) individuals. There were, however, fine intervening translucent lines within the opaque band formed after the tetracycline injection. The tetracycline may have caused some disturbances in the growth during this period that were responsible for these poorly

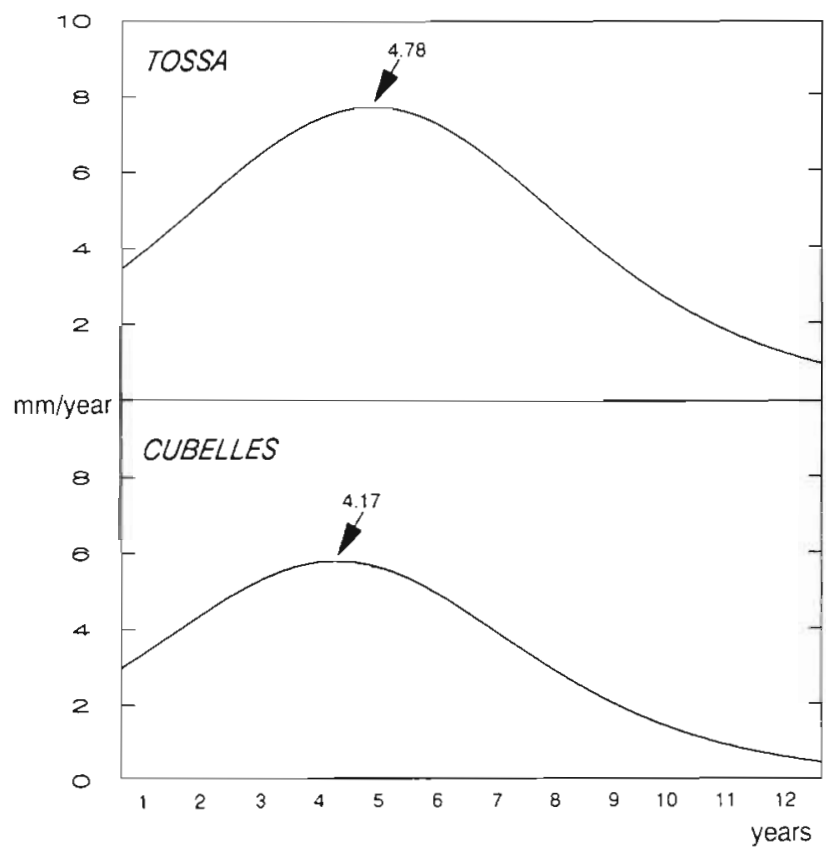

Fig. 4. Paracentrotus lividus. Growth rates obtained from the derivative of the growth funcions at both localities. The maxima and their corresponding ages (in years) are indicated

defined subsidiary marks. This preliminary result indicated that the period of growth (opaque band formation) was mostly found between March and July, although the observation of marked specimens at later times will be more informative to confirm the pattern of band deposition and avoid the influence of short-term effects of the marking procedure (reported also by Gage 1991).

$\%$ opaque marginal band

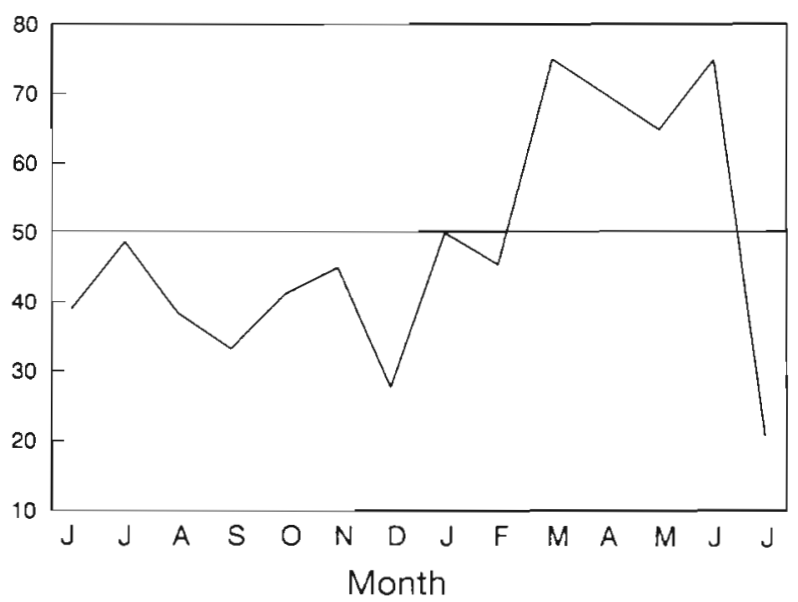

Fig. 5. Paracentrotus lividus. Percent of individuals in which the marginal growth mark at the edges of the plates was an opaque band during the study period at Tossa 


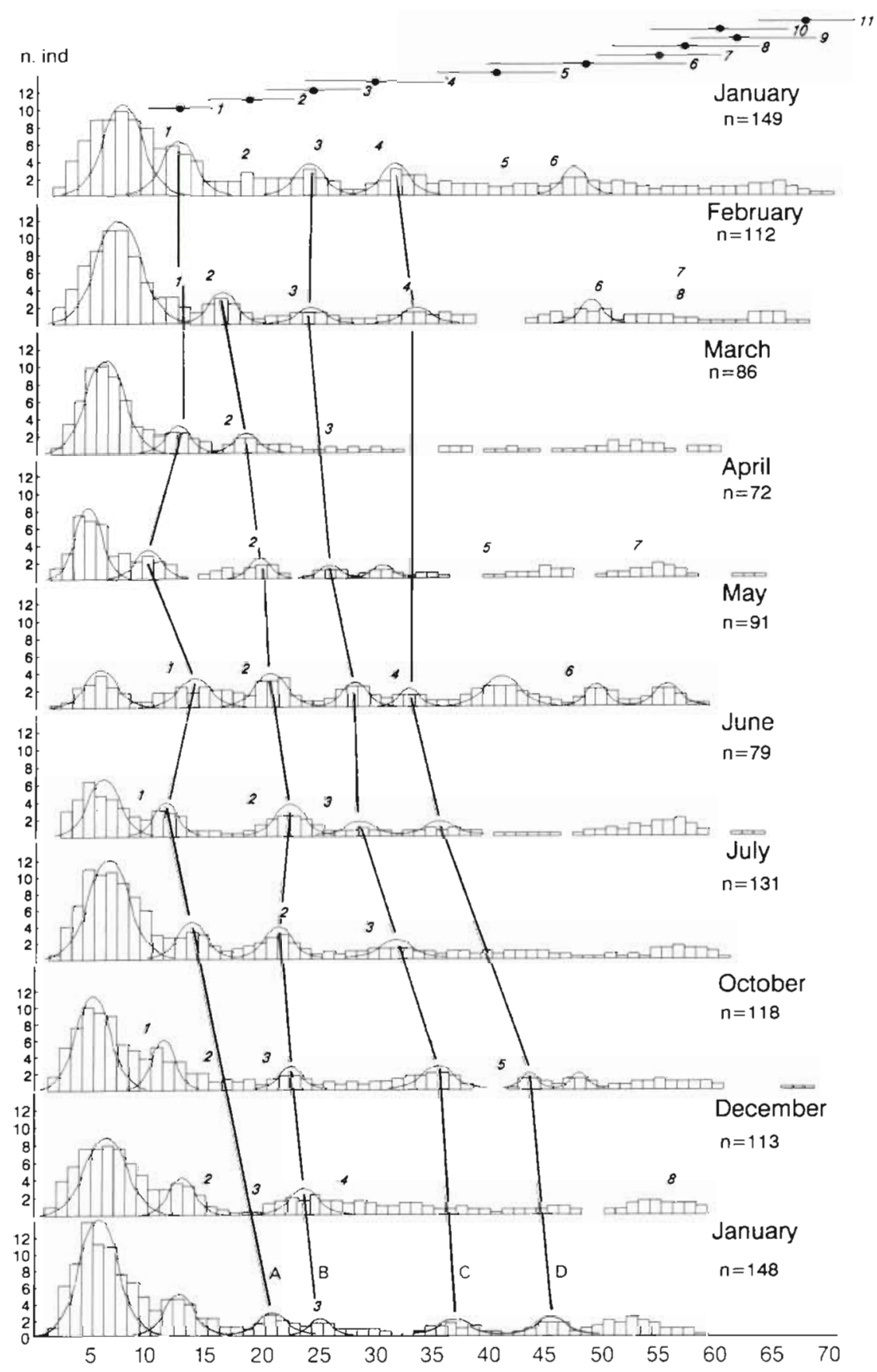

Fig. 6. Paracentrotus lividus. Size-frequency distributions of specimens measured along a fixed transect at Tossa. Horizontal bars at the top of figure are means and standard deviations of the diameters of the different ring-classes (all months pooled) obtained at this locality. The mean diameters of the sea urchins collected in any particular month featuring $n$ dark rings was indicated by the corresponding number $n$ at the appropriate place of the size distribution. This information was included only when more than 3 individuals were available per month and ring class. The more distinct normal components according to Battacharya's method are depicted (see 'Results: size-frequency distribution'). The inferred time course of the cohorts of 1991 (A), 1990

(B), 1989 (C), and 1988 (D) is indicated

\section{Size-frequency distributions}

Figs. $6 \& 7$ present, in size classes of $1 \mathrm{~mm}$, the distributions obtained at Tossa (1099 individuals measured) and Cubelles (1002 individuals) during the months studied. A moving average 3 points wide was used to smooth the series. Information on the sizes of the different ring classes in each month, as well as for all months pooled (top of figures), is also included (see figure legends)
No attempt was made to decompose the complete size distributions in modal components, given the low numbers of individuals in some months and the evidence of overlap of the larger cohorts. Instead, the Battacharya method was used to ascertain the normal components which showed up more distinctly in the data, i.e. those with a correlation coefficient higher than 0.6 and a separation index higher than 2 (Pauly \& David 1981). Usually, no components were identified above the sizes at which overlap occurs. The normal 


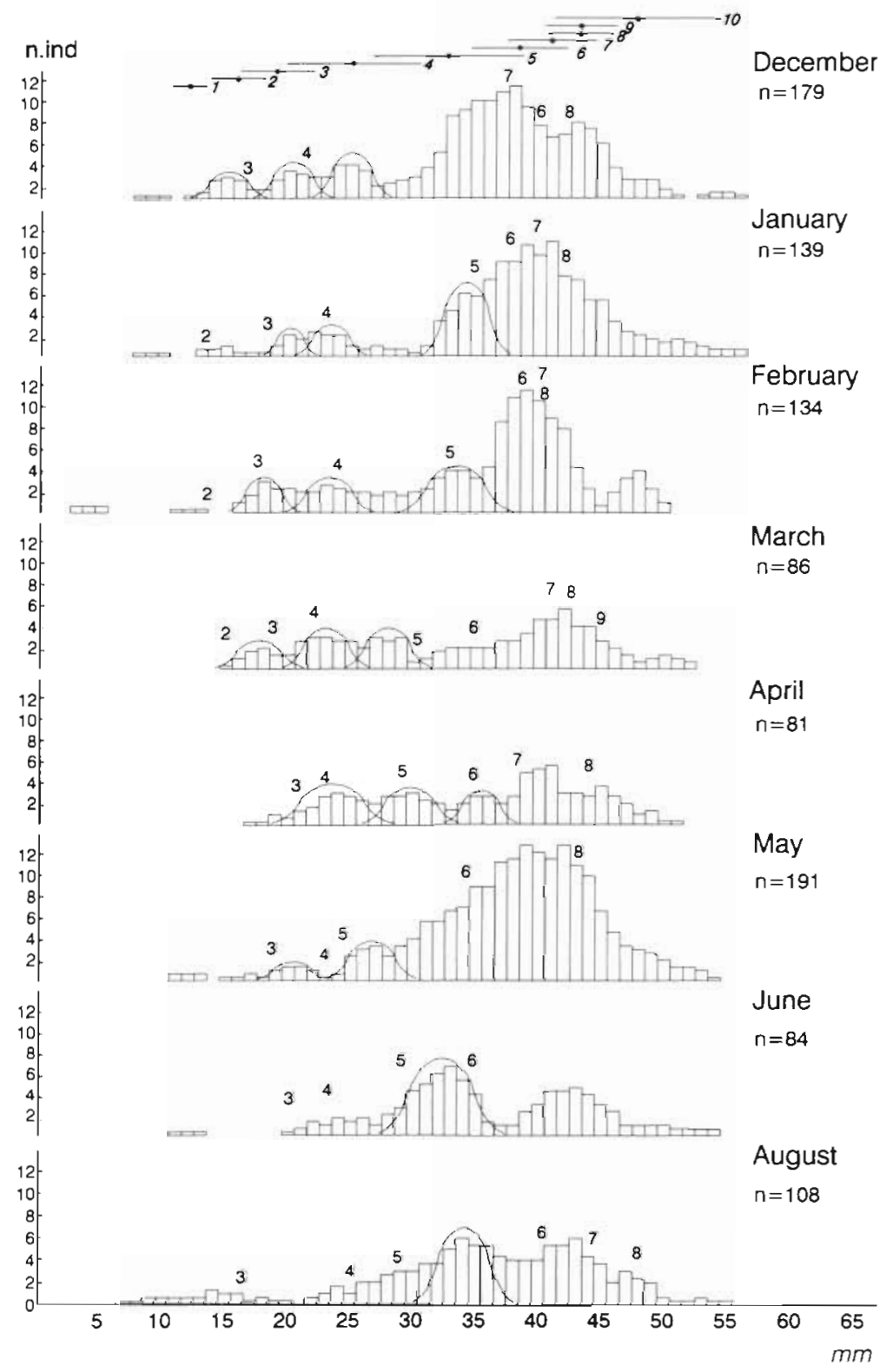

Fig. 7. Paracentrotus lividus. Size-frequency distributions as in Fig. 6 but for transect at Cubelles

curves in Figs. $6 \& 7$ are the normal components identified with these constraints.

The structure in the stable community (Fig. 6, note that there were missing data in August, September, and November) was multimodal, and in many months there was a close correspondence between the means of the normal components and the means of the diameters of the ring classes of sea urchins collected in the same month (see, for instance, the structure in February or May). It should be remembered that the measures of ring classes were taken in the laboratory, while the size histograms were obtained from underwater measurements on living animals. The latter were obviously about 1 or
$2 \mathrm{~mm}$ overestimated with respect to the former. The most abundant classes always corresponded to the smallest specimens (less than $10 \mathrm{~mm}$ ). These tiny individuals could be confused visually with specimens of Genocidaris maculata Agassiz, an echinoid which hardly reaches $10 \mathrm{~mm}$ in diameter. However, complementary samplings confirmed that the population of sea urchins less than $10 \mathrm{~mm}$ in diameter at this site was composed almost exclusively (about $98 \%$ ) of Paracentrotus lividus at all seasons.

The picture for the unstable community was quite different (Fig. 7), The size distribution was variable from one month to the next, and it shifted from a multimodal to a bi- (e.g. June) or uni-modal (e.g. May) shape without apparent regularity. The smallest size classes were always poorly represented (in fact, few individuals less than $20 \mathrm{~mm}$ in diameter were recorded), and most specimens were between 30 and $50 \mathrm{~mm}$, a range of sizes in which a superposition of cohorts was suggested from the growth ring measurements. Although the study ended in August, the data for the 8 mo studied seem enough to assign a fluctuating pattern to this community. Some normal components were identified (Fig. 7), but most of the distribution lay in the zone above $40 \mathrm{~mm}$, where no attempt was made to distinguish cohorts, which would have no meaning due to the overlap of the true annual classes

The instability of the modal components from one month to the next prevented further studies of the histograms at Cubelles. In the stable community, however, the modes below the zone of overlap were reasonably identified and followed with the aid of the data from the ring measurements. Assuming that there was a major recruitment event in the year, and that the translucent ring is primarily formed in summer, we present in Fig. 6 the hypothesized growth of 4 annual classes corresponding to the sea urchins settled in 1992, 1991, 1990 and 1989. From the sequential increases in size of the frequency modes, we calculated the means of the monthly gains in size of these 4 cohorts (Fig. 8). Important growth variations during the year can be seen, with more active growth in winter-spring and lower rates in August and autumn. Note that the graph in Fig. 8 is quite coincident with the one in Fig. 5 on the formation of the opaque band. 


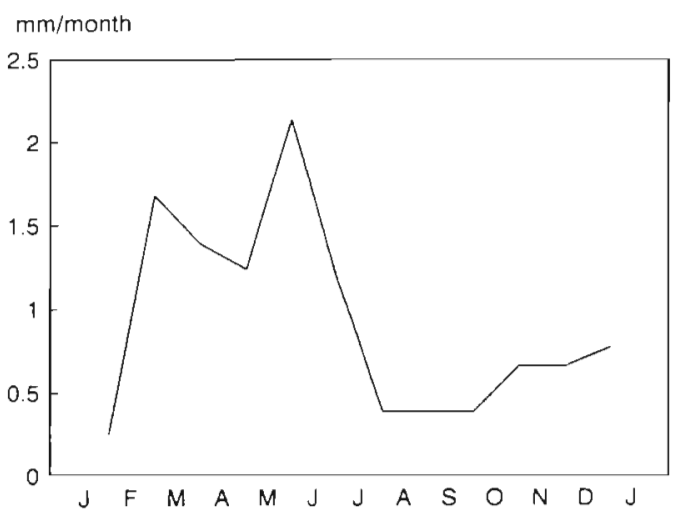

Fig. 8. Paracentrotus lividus. Means of the monthly growth rates (in $\mathrm{mm} \mathrm{mo}^{-1}$ ) of the 4 cohorts identified at Tossa

Fig. 9 showed the size distributions of the individuals measured at Tossa and Cubelles, for all months pooled. The differing population structure is evident. At Tossa where a whole year has been monitored, this graph can be taken as an indication of the structure of the population. The highest abundance was found at sizes between 4 and $8 \mathrm{~mm}$ (below $4 \mathrm{~mm}$ in size the population was not adequately sampled by our method).

The decrease in numbers from these sizes onwards may be taken as an estimate of the mortality of the

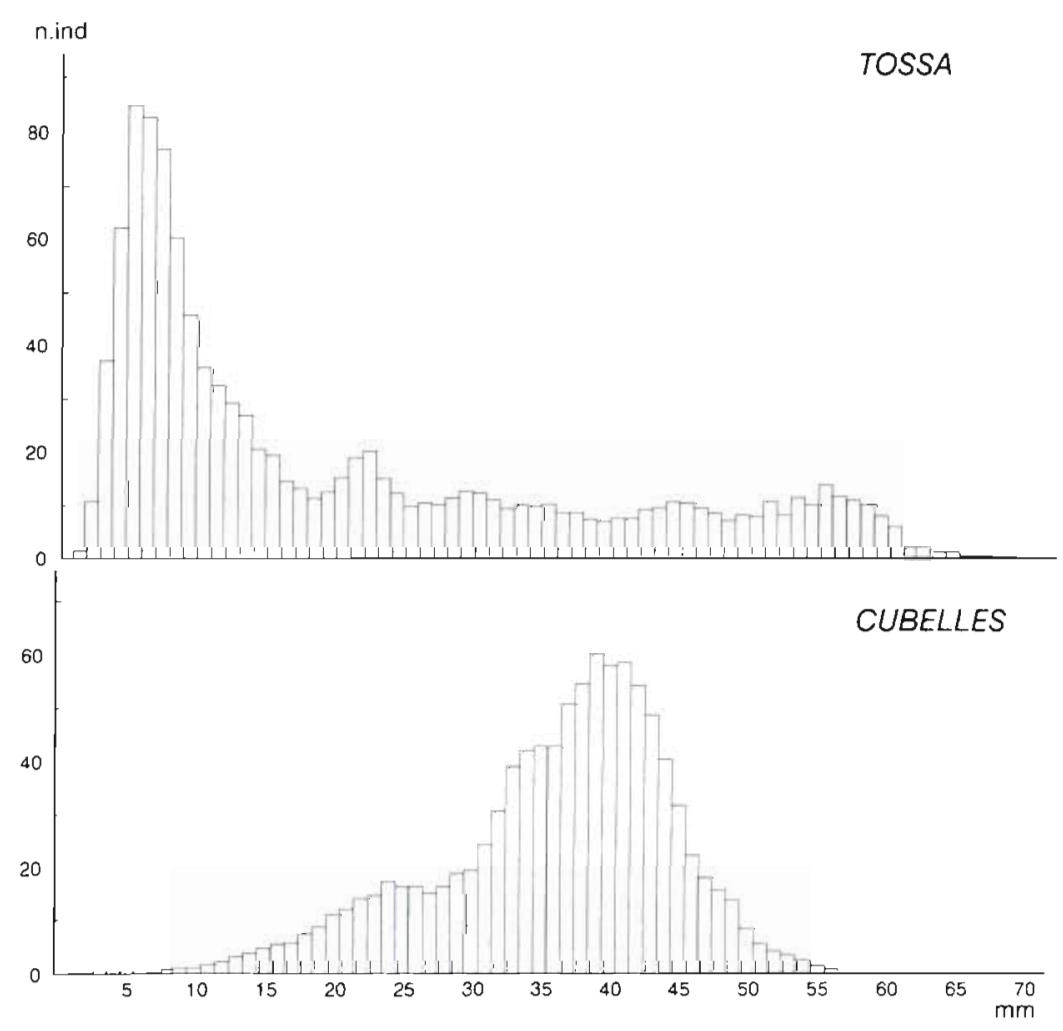

Fig. 9. Paracentrotus Lividus. Size-frequency histograms obtained at both localities by pooling the measures corresponding to the whole study period population, although the fact that the yearly recruitments (and, possibly, the yearly mortality) were variable in intensity prevented a smooth decrease in the right part of the size distribution (the 'bumps' corresponding to the more succesful year-classes), and made mortality estimates only indicative. To obtain such a gross estimate of the mortality, we fitted a simple exponential function of abundance $(N)$ as a function of time $N_{t}=N_{0} \mathrm{e}^{-Z t}$, or $\ln \left(N_{t}\right)=\ln \left(N_{0}\right)-Z t$ to the data on number of individuals per age (by transforming the size values in $\mathrm{mm}$ to age in years using the corresponding growth equation estimated above). The value of $Z$ (the instantaneous rate of mortality on a yearly basis) calculated for the above regression at Tossa was $0.349\left(\mathrm{r}^{2}\right.$ of the regression $\left.=0.716\right)$, or an annual mortality rate of $1-\mathrm{e}^{2}=0.295$ for specimens larger than $5 \mathrm{~mm}$. It is clear from Fig. 9, however, that the mortality rates were not constant throughout life, and the decrease in number of individuals was steeper at sizes below $20 \mathrm{~mm}$ (ca $2.5 \mathrm{yr}$ ). The instantaneous mortality rate for specimens below this size was $Z=$ $0.600\left(\mathrm{r}^{2}=0.957\right)$ or 0.451 annual rate. The corresponding figures for specimens larger than $20 \mathrm{~mm}$ were $Z=0.258, \mathrm{r}^{2}=0.610$, and $1-\mathrm{e}^{-Z}=0.227$. At the unstable community, the smaller classes were underrepresented, and the graph indicated a dominance of forms larger than $30 \mathrm{~mm}$. There was a much steeper decrease in the number of individuals above $40 \mathrm{~mm}$, indicating a higher mortality at this site. However, estimating mortality parameters only in this part of the size distribution is not advisable, since we would miss most of the size classes present in the zone and because information on a complete annual period was not available.

\section{DISCUSSION}

The use of skeletal growth zones seemed to be the best method for estimating growth in the population studied, due to the difficulty in correctly identifying and interpreting the sequence of size-frequency modes, and the overlap in size of the older ageclasses. Alternating phases of high (in which opaque bands are deposited) and low (in which transluced bands are formed) growth have been attributed to the annual reproductive cycle found in many echinoids and, therefore, an annual pattern of band formation has been assumed in studies of growth 
(Gage 1991 and references therein). However, care must be taken until evidence is obtained that the bands are formed seasonally in any particular species under study (Pearse \& Pearse 1975). A further difficulty with the growth bands is the formation of supplementary translucent rings of low growth due to episodic stresses. This can produce an overestimation of the age, especially in old specimens that are more likely to have undergone such stresses.

Validation of the annual pattern of band formation can be achieved indirectly, from the agreement between data obtained from growth bands and from the study of size-frequency distributions (Crapp \& Willis 1975, Lumingas \& Guillou 1994), or more directly by following the timing of formation of the bands by considering the outermost ring in sequential samples (Taki 1972a, b, Crapp \& Willis 1975). Tetracycline labelling has also been used to ascertain the consistency of the bands formed after the tetracycline mark with an annual pattern (Taki 1972a, b, Gage 1991, 1992a, b). In the case of Paracentrotus lividus, Smith (1980) remarked upon the distinctiveness of the growth banding in this species as compared to other echinoids, and Crapp \& Willis (1975) concluded from several sources of evidence that the growth structures can be used to age individuals of this species from Ireland on the basis of an annual period of high growth.

Our results on the type of marginal band found in the plates throughout the year, as well as the preliminary information from the tetracycline-labelled individuals, support the annual nature of the pattern of band deposition. The good agreement between the population structure derived from size-frequency data and from ring class data also supports the validity of this method. However, the possibility of overestimation of age in the larger specimens due to the above mentioned problem with the supplementary bands should be taken into account. This is more likely to accur in the unstable than in the stable community.

Selection of a suitable growth function is also a crucial step (Ebert \& Russell 1993). The inaccuracy of functions that do not allow a sigmoid shape of the growth curve (such as the Von Bertalanffy model), especially when juveniles are included in the analyses, has been recognized (Gage \& Tyler 1985, Sime \& Cranmer 1985). Among the functions describing a sigmoid curve, we tried the Richards, Compertz, and single logistic functions (Richards 1959, Schnute 1981), and finally adopted the Gompertz model on the basis of its lower residual sum of squares. Gage et al. (1986) and Gage \& Tyler (1985) also adopted the Gompertz model after comparing different functions. On the other hand, the Richards model was found to be most appropriate by Kenner (1992) and Ebert \& Russell
(1992). A compromise should be sought between identifying the best fitting function for each set of data and the adoption of a common function allowing for comparison among studies. At present it is not clear which function will provide the best compromise between these needs.

The growth equations fitted to the data showed noticeably lower growth rates (the maximal one was $25 \%$ lower), as well as a smaller asymptotic size (about $30 \%$ less), in the unstable community with respect to the stable one. This result was as expected, since the scarcity and low quality of the food available in the unstable habitat (Lozano et al. 1995) was combined with more direct exposure to the surf effects in this shallow water zone, and with a higher density of the population. Food and hydrodynamism are key factors in determining the growth rate in echinoids (Ebert 1968, Himmelman 1986), which has also proved to be density dependent (Levitan 1988). The higher density and smaller sizes at the unstable site found here confirm the hypotheses that food limitation has more influence on the size than on the numbers of sea urchins (Ebert 1968) and that density-dependent mortality is not as prevalent in this group as in other invertebrates (Andrew 1989). Besides, a higher investment in gonad production has been observed at the unstable site (Lozano et al. 1995), contributing to the shortage of resources available for somatic growth. A greater longevity at the stable site is also suggested by the fact that individuals with up to 10 (and even 11) rings have been encountered, while only 2 specimens out of 492 featured 10 rings at Cubelles, in spite of the fact that we expected more supernumerary bands in this community, as mentioned above.

Few data on growth of this species are available for comparison with our results. Allain (1978) found different sizes in 2 populations from the French Atlantic coasts, and estimated a longevity of 10 to $11 \mathrm{yr}$. In one of the populations, a Von Bertalanffy curve was fitted, obtaining an asymptotic size of $61.8 \mathrm{~mm}$, half-way between the 2 values found in our study. Azzolina (1987), in populations from French Mediterranean shores, obtained from the Von Bertalanffy equation a maximal size of $59.29 \mathrm{~mm}$ from data on growth rings (which indicated longevities up to $7.5 \mathrm{yr}$ ), and of $46.3 \mathrm{~mm}$ from growth measures in situ in enclosures. These values are similar to those observed in the unstable community and much lower than those reached at the stable site. Azzolina studied populations in a shallow water bay occupied by a Posidonia oceanica bed whose conditions may be closer to our unstable than to the stable community.

It is also worth noting that the highest growth rate is attained about 6 mo earlier in the unstable community. Although this advance is moderate, this result agrees 
with the general advance of other features, such as gonadal development and percentage of maturity (Lozano et al. 1995): the percentage of mature individuals (all year pooled) plotted against size reached the asymptotic part of the curve at sizes between 20 and $30 \mathrm{~mm}$ at Cubelles, while the asymptote was reached at sizes between 40 and $50 \mathrm{~mm}$ at Tossa. This finding cannot be accounted for by only the smaller sizes reached at equal age at the former site (a sea urchin of $25 \mathrm{~mm}$ at the unstable site is, according to the growth function, $4.164 \mathrm{yr}$ old, while a $45 \mathrm{~mm}$ specimen in the stable population is $6.283 \mathrm{yr}$ old).

The use of size-frequency data is useful in describing the general structure of the populations, but ascertaining growth parameters from them is difficult unless the different components or cohorts are well defined and constant through time. This is rarely the case with echinoids, and changing or poorly defined distributions are commonly encountered (Gage et al. 1986 Fénaux et al. 1987, Rowley 1990, Lumingas \& Guillou 1994). The overlap of the older age classes in the same size range is a further difficulty in this group (Allain 1978, Azzolina \& Boudouresque 1984). Our analyses are thus restricted to the more distinct components that could be determined using the Battacharya method, and the data on ring classes are incorporated to support the results. Only in the stable community were the modes consistent enough in successive sampling times to suggest a sequence of growth for some cohorts. This complemented the data from the growth function fitted to the size-at-age data by adding a seasonal element. The results showed a seasonally variable growth rate, in which the highest growth is obtained during spring and beginning of summer. This is fully consistent with the data on reproductive periodicities and on deposition of the large opaque band. The period of high growth corresponds to the phase in which mature ova are accumulated in the gonads, and the slow growth phase commenced just after spawning, when gonadal development restarts and the nutritive layer is restored (Lozano et al. 1995). Azzolina (1987) similarly found the highest growth rate of Paracentrotus lividus in the French Mediterranean in spring.

The evidence obtained from the structure of the population, together with larval settlement data (presented in Lozano et al. 1995) indicated that markedly different dynamics underlie the arrival of new members to the 2 populations. The recruitment at Tossa, although variable in intensity between years, appeared more constant and predictable, resulting in a population in which the younger size classes predominated (Figs. 6 \& 9). At Cubelles, no recruitment was observed in the $2 \mathrm{yr}$ of study, and the evidence from the size distributions (Figs. $7 \& 9$ ) strongly suggested that this population underwent a strong limitation in larval settlement.

Echinoids can feature a high interannual variation in recruitment, resulting in exceptionally good years intermingled with periods without apparent recruitment (Ebert 1983). Recruitment limitation has been described in open populations of Diadema antillarum (Karlson \& Levitan 1990), and this also seems to be the case at Cubelles. Either the population is maintained by episodic recruitment events, such as those described by Pearse \& Hines (1987) for Strongylocentrotus purpuratus (and the last one must have taken place several years before this study, judging from the absence of small individuals), or it is dependent on migration of larger forms. The latter hypothesis seems the most likely, since after storms it is common to find high numbers of dead sea urchins on the beach at this locality. It is likely that, during storms, individuals coming from a deeper zone (possibly from a nearby Posidonia oceanica bed) reached the zone of study. Although many of them, together with sea urchins already installed in the sampled zone, would be cast onto the beach, some could remain in this shallow area. Besides, the movement of the boulders due to wave action would provoke high mortalities in the population. All this can explain the changing size structure and fluctuating densities found at Cubelles.

In a broad sense, recruitment means addition of new individuals to a population and thus refers not only to larval settlement, but also to immigration (Ebert 1983). We suggest that the reproductive component of recruitment predominates in the stable community, while the migration component explains the dynamics of recruitment more fully in the unstable one.

The population structure found in our 2-site comparison is markedly different from that reported by Himmelman (1986) on Strongylocentrotus droebachiensis at 3 sites along a gradient of exposure in Newfoundland. There, the mean size-frequency distributions showed the lack of juveniles at the more protected site, while specimens of the smaller size classes were the most abundant in the exposed zone. The lack of recruitment (or, alternatively, the high juvenile mortality) in the protected area was explained by Himmelman by the high temperatures of the water in this zone, which may not be tolerated by the larvae, and by factors associated with water movement. These contrasting results clearly indicated that the distinction between exposed and sheltered habitats, although important, does not in itself determine the dynamics of the inhabiting echinoid populations, and other factors must be taken into account in each particular case.

Taken together, the results obtained here and those reported in Lozano et al. (1995) indicated a high plas- 
ticity in most of the biological parameters studied, which conferred a wide range of adaptive responses to environmental conditions to the sea urchins of this species. In particular, the comparison of a stable and an unstable community suggested that the population inhabiting the former was more settlement-dependent, while the latter population was more migrationdependent, with higher fluctuations of abundance and a changing population structure. Longevity was greater and mortality lower in the stable community. There was an advancement of the age at maturity, and the maximal growth rate was attained at younger ages in the unstable community. The investment in reproduction was higher at the unstable site in spite of the poorer food available and the higher density, and as a result the growth rates were markedly lower and the sizes smaller than in the stable habitat.

Acknowledgements. The authors are grateful to Dr M. Ballesteros, L. Dantart, J. Lozano, J. Galera, G. Morera and $\mathrm{S}$. Carner, from the University of Barcelona, for field and laboratory assistance. This work was supported by the Fisheries Department of the Catalan Government.

\section{LITERATURE CITED}

Allain JY (1978) Age et croissance de Paracentrotus lividus (Lamarck) et de Psammechinus miliaris (Gmelin) des côtes nord de Bretagne (Echinoidea). Cah Biol Mar 19:11-21

Andrew NL (1989) Contrasting ecological implications of food limitation in sea urchins and herbivorous gastropods. Mar Ecol Prog Ser 51:189-193

Azzolina JF (1987) Evolution à long terme des populations de l'oursin comestible Paracentrotus lividus dans la baie de Port-Cros (Var, France). In: Boudouresque CF (ed) Colloque international sur Paracentrotus lividus et les oursins comestibles. GIS Posidonie publ, Marseille, p 257-269

Azzolina JF (1988) Contribution a l'étude de la dynamique des populations de l'oursin comestible Paracentrotus lividus (Lamarck). Croissance, recrutement, mortalité, migrations. PhD thesis, Univ Aix-Marseille II

Azzolina JF, Boudouresque CF (1984) Donnees preliminaires sur la croissance in situ de l'oursin comestible Paracentrotus lividus (Echidae) dans l'herbier a Posidonia oceanica de la baie de Port-Cros (Var-France). In: Boudouresque $\mathrm{CF}$, De Grissac JA, Olivier J (eds) International workshop on Posidonia oceanica beds, Vol 1. GIS Posidonie publ, Porquerolles, p 283-289

Battacharya CG (1967) A simple method of resolution of a distribution into gaussian components. Biometrics 23:115-135

Byrne M (1990) Annual reproductive cycles of the commercial sea urchin Paracentrotus lividus from an exposed intertidal and a sheltered subtidal habitat on the west coast of Ireland. Mar Biol 104:275-289

Cellario C, Fénaux L (1990) Paracentrotus lividus (Lamarck) in culture (larval and benthic phases): parameters of growth observed during two years following metamorphosis. Aquaculture 84:173-188

Crapp GB, Willis ME (1975) Age determination in the sea urchin Paracentrotus lividus (Lamarck), with notes on the reproductive cycle. J exp mar Biol Ecol 20:157-178
Ebert TA (1968) Growth rates of the sea urchin Strongylocentrotus purpuratus related to food availability and spine abrasion. Ecology 49:1075-1091

Ebert TA (1983) Recruitment in echinoderms. In: Jangoux M, Lawrence JM (eds) Echinodem studies, Vol 1. Balkema AA, Rotterdam, p 169-203

Ebert TA, Russell MP (1992) Growth and mortality estimates for red sea urchin Strongylocentrotus franciscanus from San Nicolas Island, California. Mar Ecol Prog Ser 81:31-41

Ebert TA, Russell MP (1993) Growth and mortality of subtidal red sea urchins (Strongylocentrotus franciscanus) at San Nicolas Island, Calıfornia, USA: problems with models. Mar Biol 117:79-89

Fénaux L, Etienne M. Quelart G (1987) Suivi ecologique d'un peuplement de Paracentrotus lividus (Lamark) dans la baie de Vilafranche sur mer. In: Boudouresque CF (ed) Colloque international sur Paracentrotus lividus et les oursins comestibles. GIS Posidonie publ, Marseille, p $187-197$

Gage JD (1991) Skeletal growth zones and age markers in the sea urchin Psammechinus milliaris. Mar Biol 110:217-228

Gage JD (1992a) Growth bands in the sea urchin Echinus esculentus: results from tetracycline-mark/recapture. J mar biol Ass UK 72:257-260

Gage JD (1992b) Natural growth bands and growth variability in the sea urchin Echinus esculentus: results from tetracycline tagging. Mar Biol 114:607-616

Gage JD, Tyler PA (1985) Growth and recruitment of the deep-sea urchin Echinus affinis. Mar Biol 90:41-53

Gage JD, Tyler PA, Nichols D (1986) Reproduction and growth of Echinus acutus var norvegicus (Düben \& Koren) and E elegans (Düben \& Koren) on the continental slope off Scotland. J exp mar Biol Ecol 101:61-83

Himmelman JH (1986) Population biology of green sea urchins on rocky barrens. Mar Ecol Prog Ser 33:295-306

Jensen $M$ (1969) Age determination of echinoids. Sarsia $37: 41-44$

Karlson RH, Levitan DR (1990) Recruitment limitation in open populations of Diadema antillarum: an evaluation. Oecologia 82:40-44

Kenner MC (1992) Population dynamics of the sea urchin Strongylocentrotus purpuratus in a Central California kelp forest: recruitment, mortality, growth, and diet. Mar Biol 112:107-118

King CK, Hoegh-Guldberg O, Byrne M (1994) Reproductive cycle of Centrostephanus rodgersii (Echinoidea), with recommendations for the establishment of a sea urchin fishery in New South Wales. Mar Biol 120:95-106

Kobayashi S, Taki J (1969) Calcification in sea urchins. I. A tetracycline investigation of growth of the mature test in Strongylocentrotus intermedius. Calcif Tissue Res $4: 210-223$

Levitan DR (1988) Density-dependent size regulation and negative growth in the sea urchin Dladema antillarum (Philippi). Oecologia 76:627-629

Lozano J, Galera J, López S, Turon X, Palacín C, Morera G (1995) Biological cycles and recruitment of Paracentrotus lividus (Echinodermata: Echinoidea) in two contrasting habitats. Mar Ecol Prog Ser 122:179-191

Lumingas LJL, Guillou M (1994) Growth zones and backcalculation in the sea urchin, Sphaerechinus granularis, from the Bay of Brest, France. J mar biol Ass UK 74:671-686

McGill R, Tukey JA, Larsen WA (1978) Variations of the box plots. Am Stat 32:12-16

Pauly D, David N (1981) ELEFAN I, a BASIC program for the objective extraction of growth parameters from lengthfrequency data. Meeresforsch Rep Mar Res 28:205-211 
Pearse JS, Hines AH (1987) Long-term population dynamics of sea urchins in a central California kelp forest: rare recruitment and rapid decline. Mar Ecol Prog Ser 39: $275-283$

Pearse JS, Pearse VB (1975) Growth zones in the echinoid skeleton. Am Zool 15:731-753

Richards FJ (1959) A flexible growth function for empirical use. $J \exp$ Bot 10(29):290-300

Rowley RJ (1990) Newly settled sea urchins in a kelp bed and urchins barren ground: a comparison of growth and mortality. Mar Ecol Prog Ser 62:229-240

Schnute J (1981) A versatile growth model with statistically stable parameters. Can J Fish Aquat Sci 38:1128-1140

Sime AAT, Cranmer GJ (1985) Age and growth of the North

This article was submitted to the editor
Sea echinoids. J mar biol Ass UK 65:583-588

Smith AB (1980) Stereom microstructure of the echinoid test. Spec pap Paleontol 25:4-81

Taki J (1972a) A tetracycline labeling observation on growth zones in the test plate of Strongylocentrotus intermedius. Bull Jap Soc Sci Fish 38(2):117-125

Taki J (1972b) A tetracycline labeling observation on growth zones in the jaw apparatus of Strongylocentrotus intermedius. Bull Jap Soc Sci Fish 38(3):181-188

Underwood AJ (1981) Techniques of analysis of variance in experimental marine biology and ecology. Oceanogr mar Biol A Rev 19:513-605

Zar JH (1.984) Biostatistical analysis, 2nd edn. Prentice-Hall International, Englewood Cliffs

Manuscript first received: September 13, 1994

Revised version accepted: March 16, 1995 


\title{
Sulfide stress and tolerance in the lugworm Arenicola marina during low tide
}

\author{
Susanne Völkel, Kerstin Hauschild, Manfred K. Grieshaber
}

Institut für Zoologie, Lehrstuhl für Tierphysiologie, Heinrich-Heine-Universität, Universitätsstr. 1, D-40225 Düsseldorf, Germany

\begin{abstract}
In the present study environmental sulfide concentrations in the vicinity of and within burrows of the lugworm Arenicola marina during tidal exposure are presented. Sulfide concentrations in the pore water of the sediment ranged from 0.4 to $252 \mu \mathrm{M}$. During $4 \mathrm{~h}$ of tidal exposure no significant changes of pore water sulfide concentrations were observed. Up to $32 \mu \mathrm{M}$ sulfide were measured in the water of lugworm burrows. During $4 \mathrm{~h}$ of low tide the percentage of burrows containing sulfide increased from 20 to $50 \%$ in July and from 36 to $77 \%$ in October A significant increase of median sulfide concentrations from 0 to $14.5 \mu \mathrm{M}$ was observed after $5 \mathrm{~h}$ of emersion. Sulfide and thiosulfate concentrations in the coelomic fluid and succinate, alanopine and strombine levels in the body wall musculature of freshly caught $A$. marina were measured. During $4 \mathrm{~h}$ of tidal exposure in July the percentage of lugworms containing sulfide and maximal sulfide concentrations increased from $17 \%$ and $5.4 \mu \mathrm{M}$ to $62 \%$ and $150 \mu \mathrm{M}$, respectively. A significant increase of median sulfide concentrations was observed after 2 and $3 \mathrm{~h}$ of emersion. In October, changes of sulfide concentrations were less pronounced. Median thiosulfate concentrations were 18 to $32 \mu \mathrm{M}$ in July and 7 to $12 \mu \mathrm{M}$ in October No significant changes were observed during tidal exposure. Succinate accumulated in the tissue of A. marina, indicating the onset of an environmental and sulfide dependent anaerobiosis. Recovery experiments after $4 \mathrm{~h}$ of tidal exposure showed that sulfide is completely removed from the coelomic fluid after $30 \mathrm{~min}$. Succinate levels began to decrease immediately after the disappearance of sulfide, reaching control levels after 60 min of recovery. Thiosulfate concentration showed a significant increase after $30 \mathrm{~min}$, indicating that internal sulfide is removed by its oxidation to thiosulfate. The present study shows that $A$. marina exhibits the same mechanisms of sulfide tolerance under habitat conditions as under experimental conditions. In addition, it is demonstrated that the lugworm is able to recover from tidal sulfide stress within $1 \mathrm{~h}$.
\end{abstract}

KEY WORDS: Arenicola marina S Sulfide tolerance - Tidal exposure - Sediment - Recovery

\section{INTRODUCTION}

Animals inhabiting the sediment of the intertidal zone can be exposed to pronounced fluctuations of abiotic conditions. The tidal rise and fall of the sea causes periodical changes in temperature, salinity and oxygen supply. The lugworm Arenicola marina lives about 10 to $30 \mathrm{~cm}$ deep in the sediment of intertidal flats. During high tide its U-shaped burrow is irrigated by peristaltic movements of its body wall thus providing the animal with oxygen (Krüger 1971). At low tide when the burrow is emersed, ventilation becomes impossible and the lugworm is exposed to increasing hypoxia. Jones (1955) demonstrated that the $\mathrm{P}_{\mathrm{O}_{2}}$ in the remaining water of the lugworm burrow decreases from about 33 to 13 torr during 2 h of tidal emersion. Correspondingly, blood oxygen content drops nearly to zero within the first hour of tidal emersion (Toulmond 1973). In the hypoxic period $A$. marina reduces its ventilatory movements and oxygen consumption and switches from aerobic to anaerobic metabolism (Schöttler et al. 1984a, Toulmond \& Tchernigovtzeff 1984, Toulmond 1987, Grieshaber et al. 1992). Thus, the accumulation of typical anaerobic metabolites such as succinate, acetate and propionate in the body wall tissue and blood of $A$. marina was observed during tidal exposure (Pionetti \& Toulmond 1980, Schöttler et al. 1984 b). When the tide comes back in, the burrow is ventilated again and the lugworm can return to an aerobic metabolism. Pörtner et al. (1979) showed that 
A. marina recovered from anoxia with most of the tissue metabolites reach control levels during 1 to $2 \mathrm{~h}$ of normoxic incubation.

Apart from irrigated burrows of the tubebuilding infauna, oxygen is not measurable in the pore water of the deeper layers of the marine sediment (Brafield 1964, Watling 1991). These reduced layers are commonly characterized by the presence of sulfide, which is mainly produced by sulfate-reducing bacteria (Jørgensen \& Fenchel 1974, Kröger et al. 1988). Sulfide concentrations in the sediment pore water of marine habitats can range from a few $\mu \mathrm{M}$ up to several $\mathrm{mM}$ (see Bagarinao 1992) depending on the structure of the sediment and organic matter production (Fenchel \& Riedl 1970). The rate of sulfate reduction shows seasonal fluctuations which are mainly caused by changes of temperature and organic matter supply (Nedwell \& Floodgate 1972, Jørgensen 1977). Sulfide concentrations in sediment pore water are usually high in summer and low during the cold months (Jørgensen 1977, Völkel \& Grieshaber 1992). Diel fluctuations of sulfide can occur as a consequence of changing light conditions (De Wit et al. 1989).

In the vicinity of lugworm burrows sulfide concentrations up to $340 \mu \mathrm{M}$ have been observed (Groenendaal 1979, Völkel \& Grieshaber 1992). Sulfide is assumed to diffuse from the pore water along the chemical gradient into the lugworm burrow (Aller 1980. Waslenchuk et al. 1983). During high tide sulfide may be delivered to the overlying water as the lugworm irrigates its burrow. Sulfide is, moreover, likely to be oxidized rapidly by the oxygen-rich seawater (Cline \& Richards 1969, Millero 1986). Sulfide will therefore only be rarely found in burrows which are covered by tide. During tidal exposure, however, the burrow water is stagnant and becomes hypoxic isee above). Sulfide diffusing into the burrow cannot be flushed out or oxidized and Arenicola marina may be exposed to increasing sulfide concentrations as long as the burrow is emersed. Arp et al. (1992), for example, measured sulfide concentrations up to $66 \mu \mathrm{M}$ in the burrow water of Urechis caupo after $2 \mathrm{~h}$ of tidal exposure. As soon as the tide comes back in, the worm is able to ventilate again and sulfide will be removed from the burrow. A. marina is thus exposed not only to a repetitive lack of oxygen but also to periodically changing sulfide concentrations during tidal cycles.

Sulfide is a strong inhibitor of the cytochrome c oxidase (National Research Council 1979). Despite sulfide's toxicity, numerous organisms possess several mechanisms of sulfide tolerance and can live in sulfide-rich habitats (for reviews see Vetter et al. 1991, Vismann 1991). Arenicola marina is highly insensitive to sulfide (Groenendaal 1980). Its sulfide tolerance has been investigated in the laboratory and is based upon
3 main strategies: (1) in the presence of oxygen, sulfide entering the body is rapidly oxidized to thiosulfate which accumulates in the coelomic fluid of $A$. marina. The oxidation of sulfide could be localized in the mitochondria of its body wall tissue (Völkel \& Grieshaber 1992, 1994). (2) During hypoxia, the sulfide concentration in the body of $A$. marina is reduced by the acidification of the coelomic fluid (Groenendaal 1981, Völkel \& Grieshaber 1992). (3) The increase of sulfide in the body can be tolerated by switching to an anaerobic metabolism as indicated by the accumulation of anaerobic metabolites (Völkel \& Grieshaber 1992, 1994, see also Grieshaber et al. 1992). Although these mechanisms have been demonstrated under extreme experimental conditions, up to now it is not known whether they also play a role in the lugworm's habitat. The aim of this study, therefore, was (1) to determine the environmental sulfide concentrations to which A. marina is exposed during prolonged low tide, (2) to investigate whether A. marina exhibits the same mechanisms of sulfide tolerance in its natural habitat as under experimental conditions, and (3) to investigate the time course of recovery of $A$. marina from sulfide exposure during tidal emersion when reimmersed.

\section{MATERIAL AND METHODS}

Study site and sampling conditions. The studies took place at a mudflat located at the harbor of St. Pol de Léon, Brittany, France (English Channel). The site is characterized by a high population density of Arenicola marina. Sampling was performed during July 1991, July and October 1992 and October 1993 and 1994 when tidal heights were 0.9 to $1.5 \mathrm{~m}$ and peaks of low tide were around noon. All environmental and animal data were obtained within an area of about $10 \times 10 \mathrm{~m}$ which was exposed for 4 to $5 \mathrm{~h}$ during low tide. Sampling started as soon as the water had receded $(t=0)$ and was repeated after 1, 2, 3 and $4 \mathrm{~h}$ of emersion. During collecting trips air temperatures ranged from 12.5 to $24.9^{\circ} \mathrm{C}$ in July and 4.8 to $12.4^{\circ} \mathrm{C}$ in October (minimal and maximal temperatures, respectively; data obtained from the Station metéorologique, Brest, France). The weather was dry during all collecting trips with the exception of 15 July 1991 and 28 October 1992 when it started to rain after $1 \mathrm{~h}$ and $3 \mathrm{~h}$, respectively.

Sulfide concentration of the pore water. Sulfideconcentration of the pore water of the sediment was determined during 3 collecting trips in July 1991. Each time pore water was sampled from 2 different sites at a depth of 10,20 and $30 \mathrm{~cm}$. Pore water samplers as described by Völkel \& Grieshaber (1992) were inserted into the sediment immediately after emersion of the 
area and remained there for $4 \mathrm{~h}$. Every hour, 0.5 to $1 \mathrm{ml}$ pore water was collected, 3 samples from each depth and site. The samples were fixed in zinc acetate and $\mathrm{NaOH}$ and analyzed for sulfide within. 1 wk with the methylene blue method (Gilboa-Garber 1971) as described by Völkel \& Grieshaber (1992).

Sulfide concentration of the burrow water. The sulfide concentration of the burrow water was determined in July 1992 and in October 1992, 1993 and 1994. Burrow water was sampled using a polyethylene tube (length $30 \mathrm{~cm}$, inner diameter $1 \mathrm{~mm}$ ) which was attached to a $1 \mathrm{ml}$ tuberculin syringe. After the removal of the lugworm's cast the tube was carefully inserted into the burrow until it was hindered by the worm. Samples of 0.5 to $1 \mathrm{ml}$ were taken from each burrow. At each time point, 2 to 3 burrows were analyzed at the same time. The first sample was taken immediately after the emersion of the burrows and additional samples were taken hourly for $4 \mathrm{~h}$. In October 1993 the period of emersion was long enough to obtain samples after $5 \mathrm{~h}$ of emersion during 1 collecting trip. Each burrow was used only once to prevent artifacts arising from diffusion from the environment. Water samples were fixed and analyzed for sulfide as described above.

Determination of sulfur compounds and anaerobic end products in freshly caught Arenicola marina. Specimens of Arenicola marina were collected in July 1991, July and October 1992 and in October 1993. During each collecting trip, 2 to 3 lugworms $\mathrm{h}^{-1}$ were collected from unanalyzed burrows during the $4 \mathrm{~h}$ of emersion. The freshly caught lugworms were quickly washed in seawater. Coelomic fluid was collected by dorsally cutting the body wall. After that, the worms were dissected and the body wall tissue was freezeclamped (Wollenberger et al. 1960) and stored in liquid nitrogen.

For determination of sulfide and thiosulfate the coelomic fluid was immediately mixed with monobromobimane $\left(3 \mathrm{mmol} \mathrm{l}^{-1}\right.$ final concentration; Calbiochem, Giessen, Germany) and HEPES/EDTA (50/5 mmol $1^{-1}, \mathrm{pH} 8.0$ ) according to a modified method described by Vetter et al. (1989). As a control, parallel samples were prepared using 2-pyridyl disulfide (Vetter et al. 1989). After a reaction time of $30 \mathrm{~min}$ methansulfonic acid $\left(25 \mathrm{mmol} \mathrm{l}^{-1}\right.$ ) was added and the samples were frozen and stored in liquid nitrogen for 2 mo at most. In the laboratory, the samples were thawed and spun for $10 \mathrm{~min}$ (14550×g , Biofuge A, Heraeus Christ, Osterode, Germany). The supernatant was immediately analyzed for sulfur compounds by high-performance liquid chromatography (HPLC) as described by Völkel \& Grieshaber (1994)

For determination of succinate, alanopine and strombine the tissue was extracted according to Beis \&
Newsholm (1975). Succinate was measured spectrophotometrically as described by Beutler (1985). Alanopine and strombine were determined by HPLC using a DX-100 Ion Chromatograph (DIONEX, Idstein, Germany) for pumping and conductivity detection. The opines were isocratically separated at $45^{\circ} \mathrm{C}$ with a Polyspher ${ }^{\mathrm{R}} \mathrm{AR}$ AC cation exchange column (100-6.5, Merck, Darmstadt, Germany) using $7.5 \times 10^{-5} \mathrm{~N} \mathrm{H}_{2} \mathrm{SO}_{4}$ as a solvent $\left(0.6 \mathrm{ml} \mathrm{min}^{-1}\right)$.

Recovery experiments. During 2 collecting trips in Octaber 1993, 12 specimens of Arenicola marina were collected after $4 \mathrm{~h}$ of emersion. The lugworms were immediately placed into $10 \mathrm{l}$ aerated seawater from their habitat and were allowed to recover in darkness. After 15, 30,60 and $120 \mathrm{~min}$, respectively, 3 worms were removed from the tank. Coelomic fluid was collected and prepared for analysis of sulfur compounds and the body wall musculature was stored for determination of anaerobic end products as described above.

Data treatment. Results are reported as single data and medians respectively. Since most of the data were not normally distributed, significance of differences between medians were evaluated using the nonparametric Mann-Whitney $U$-test (2-tailed test) at the $p=0.05$ level (Beyer 1988).

\section{RESULTS}

\section{Sulfide in the pore water of the sediment}

Sulfide concentrations in the pore water ranged from 0.4 to $252.2 \mu \mathrm{M}$ (Fig. 1). Variations were high both between different sampling sites and between different sampling days. For instance, at a depth of $10 \mathrm{~cm}$ and at $t=0 \mathrm{~h}$, sulfide concentrations from 13.7 to $177.2 \mu \mathrm{M}$ could be measured. For the first 2 collecting trips (a, 12 July; b, 13 July 1991) sulfide concentrations in the pore water tended to increase during low tide. For the third collecting trip (c, 15 July 1991) sulfide concentrations increased in the first hour of emersion but decreased during the remaining $3 \mathrm{~h}$ of emersion. In almost all cases sulfide concentrations decreased with depth, e.g. from $77.8 \mu \mathrm{M}$ (a, site $\mathrm{I}, t=4 \mathrm{~h}$ ) at a depth of $10 \mathrm{~cm}$ to $7.8 \mu \mathrm{M}$ at $30 \mathrm{~cm}$. Due to the high variability of the data changes in sulfide concentrations during low tide were not significant.

\section{Sulfide in the burrow water}

Sulfide was present in $23 \%$ of the lugworm burrows analyzed during low tide in July $1992(\mathrm{n}=26)$ with concentrations ranging from 0.2 to $32 \mu \mathrm{M}$ (Fig. 2). Immedi- 

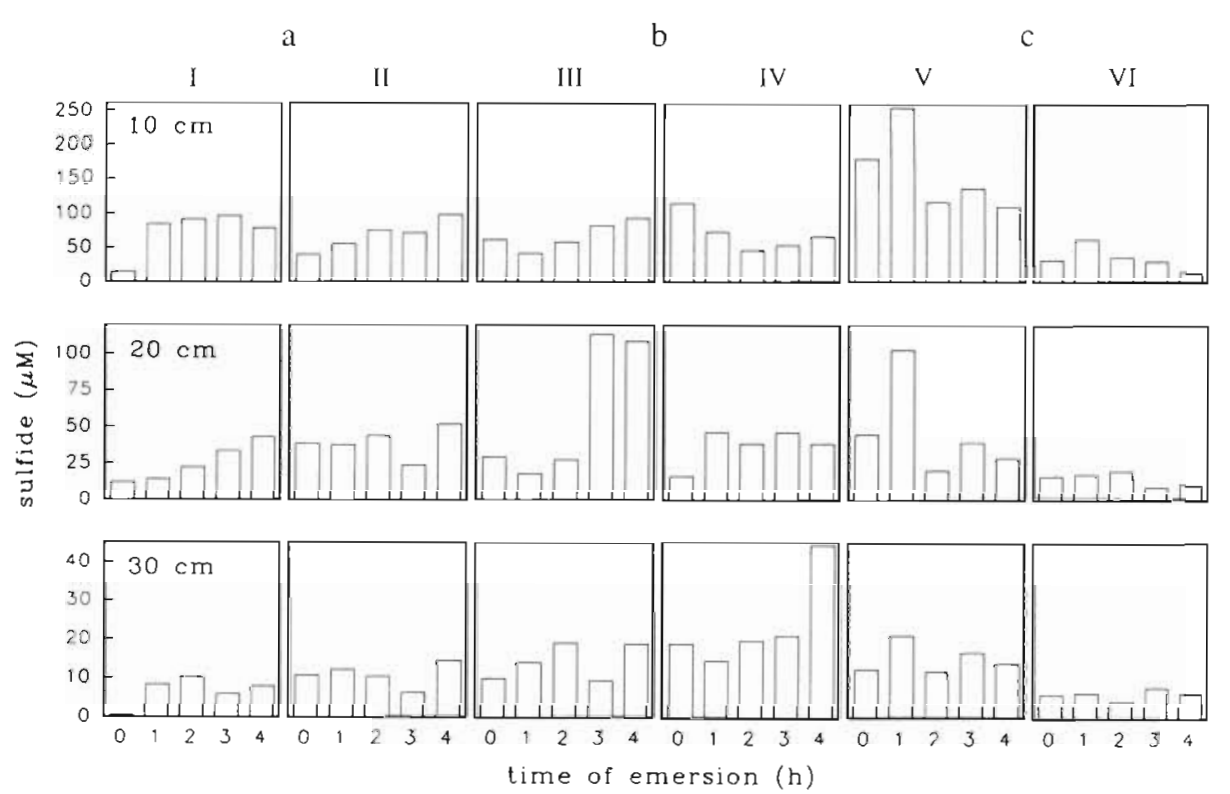

Fig. 1. Sulfide $(\mu M)$ in the pore water of the sediment in St. Pol de Léon (France). Samples were taken during tidal emersion at a depth of 10,20 and $30 \mathrm{~cm}$ at 6 different sites (I to $\mathrm{VI}$ ) and on 3 days $(a, b, c$ are 12,13 and 15 July 1991, respectively

ately after emersion and during the first $3 \mathrm{~h}$ of low tide sulfide was found in 1 of 5 burrows at most. In the same period of time median sulfide concentrations were $0 \mu \mathrm{M}$. After $4 \mathrm{~h}$ of emersion 3 of 6 burrows contained sulfide and the median concentration increased slightly, but not significantly, to $1.5 \mu \mathrm{M}$. In October 1992, 1993 and 1994 sulfide could be found in $50 \%$ of all lugworm burrows analyzed during low tide $(n=68)$. Sulfide concentrations ranged from 0.5 to $20 \mu \mathrm{M}$ (Fig. 2). Median

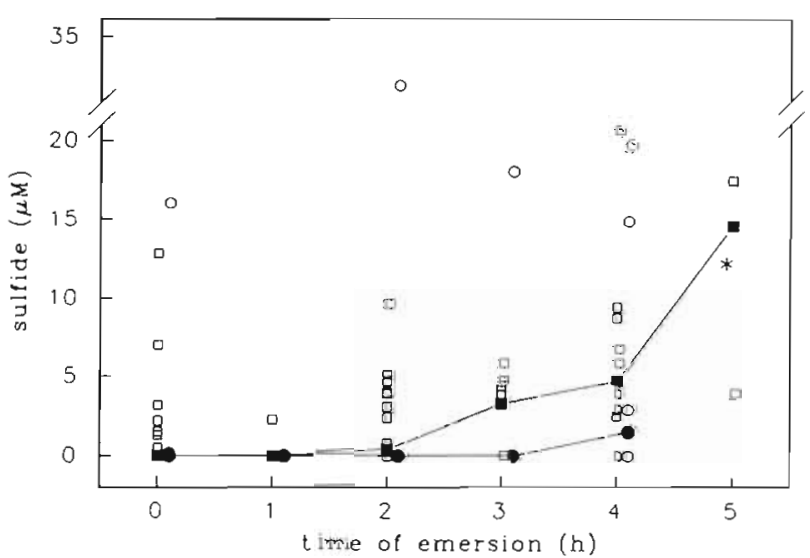

Fig. 2. Sulfide ( $\mu M()$ in the water of Arenicola marina burrows during tidal emersion. Data obtained in $(0, \bullet)$ July 1992 and $(\square, \square)$ October 1992, 1993 and 1994. Open symbols represent sulfide concentrations of single burrows; closed symbols are the respective medians. (*) Significant difference to the corresponding median at $t=0 \mathrm{~h}$. The number of analyzed burrows at $t=0,1,2,3,4$ and $5 \mathrm{~h}$ was (with the respective number of burrows containing no sulfide in parentheses): $5(4), 5(5), 5(4), 5(4), 6(3)$ and $0(0)$ in July and $14(9), 13(12)$, $16(8), 9(4), 13(3)$ and $3(0)$ in October. For clarity, July data are shifted to the right sulfide concentrations were $0 \mu \mathrm{M}$ during the first hour of emersion with 10 to $40 \%$ of the burrows containing sulfide. Median sulfide concentrations increased, although not significantly, to $4.7 \mu \mathrm{M}$ after $4 \mathrm{~h}$ of emersion, when sulfide could be measured in $77 \%$ of the burrows. After 5 h of emersion sulfide was found in all 3 burrows analyzed and median concentration rose significantly to $14.5 \mu \mathrm{M}$.

\section{Sulfur compounds in the coelomic fluid of Arenicola marina}

\section{Sulfide}

During collecting trips in July 1991 and 1992 sulfide was measured in the coelomic fluid of $46 \%$ of 37 freshly caught specimens of Arenicola marina, with concentrations ranging from 5.4 to $150 \mu \mathrm{M}$ (Fig. 3A). During tidal exposure, the percentage of lugworms containing sulfide, the medians of the sulfide concentrations and the maximal sulfide concentrations increased from $17 \%, 0 \mu \mathrm{M}$ and $5.4 \mu \mathrm{M}$ at the beginning to $62 \%, 35.1 \mu \mathrm{M}$ and $150.0 \mu \mathrm{M}$, respectively, after $4 \mathrm{~h}$ of emersion. Due to the high variations between lugworms the increase of sulfide concentration of the coelomic fluid was only significant after 2 and $3 \mathrm{~h}$ but not after $4 \mathrm{~h}$ of emersion when compared to $t=0 \mathrm{~h}$ (Fig. 3A). In October 1992 and 1993, 49 specimens of A. marina were analyzed, $57 \%$ of which contained sulfide ranging from 0.7 to $13 \mu \mathrm{M}$ (Fig. 3A). As in July, the percentage of lugworms containing sulfide, the median and the maximal sulfide concentrations increased with duration of low tide $33 \%, 0 \mu \mathrm{M}$ and 

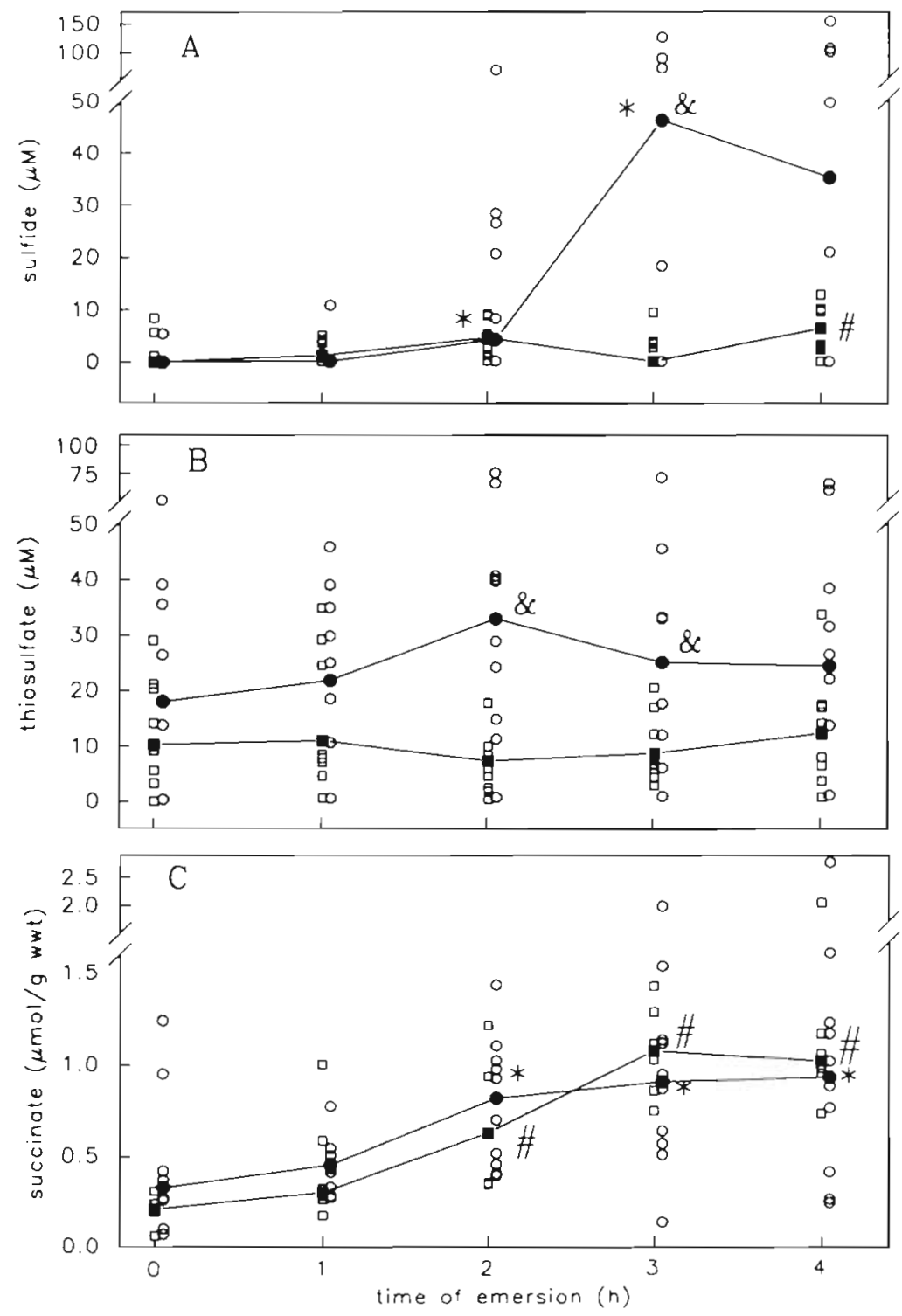

Fig. 3. Arenicola marina. (A) Sulfide $(\mu \mathrm{M})$ and $(B)$ thiosulfate $(\mu \mathrm{M})$, both in the coelomic fluid, and (C) succinate ( $\mu \mathrm{mol} \mathrm{g}^{-1}$ wet $\mathrm{wt}$ ) in the body wall tissue of freshly caught lugworms during tidal emersion. Data obtained in $(0, \bullet)$ July 1991 and 1992 and $(\square, \square)$ October 1992 and 1993. Open symbols represent data of individual lugworms; closed symbols are the respective medians. * \# indicate significant differences of the medians to the corresponding median at $t=0 \mathrm{~h}$ (*-July, \#: October). \&: significant difference between July and October values. For clarity, July data are shifted to the right. The number of lugworms analyzed for each component at $t=0,1,2,3$ and $4 \mathrm{~h}$ was (with the number of lugworms containing no sulfide, thiosulfate or succinate in parentheses): (A) sulfide: $6(5), 7(6), 9(4), 7(2)$ and $8(3)$ in July and $9(6), 9(3), 11(3), 11(7)$ and $9(2)$ in October; (B) thiosulfate: $9(3), 10(3), 11(2), 10(1)$ and $10(3)$ in July and $12(1), 12(0), 12(1), 12(0)$ and $10(1)$ in October; (C) succinate: $9(0), 11(0), 12(0)$. $10(0)$ and $11(0)$ in July and $5(0), 6(0), 6(0), 6(0)$ and $6(0)$ in October

$8.4 \mu \mathrm{M}$ at the beginning to $78 \%, 6.4 \mu \mathrm{M}$ and $12.8 \mu \mathrm{M}$, respectively, after $4 \mathrm{~h}$ of tidal exposure). A significant increase of median sulfide concentrations could only be measured after $4 \mathrm{~h}$ of emersion. Median sulfide con- centrations of October specimens after 3 and $4 \mathrm{~h}$ were much (significantly at $t=$ 3 h) lower than the corresponding July values $(0$ and $6.4 \mu \mathrm{M}$ as opposed to 46.0 and $35.1 \mu \mathrm{M}$ respectively; Fig. $3 \mathrm{~A}$ ). Likewise, maximal sulfide concentrations were only 9 to $13 \mu \mathrm{M}$ in lugworms collected in October as compared to 66 to $150 \mu \mathrm{M}$ in those collected in July after 2 to 4 h of emersion.

\section{Thiosulfate}

In July 1991 and 1992 thiosulfate could be measured in the coelomic fluid of $76 \%$ of the lugworms $(n=50)$. The concentrations ranged from 10.2 to $73.0 \mu \mathrm{M}$, median concentrations were 17.7 to $32.2 \mu \mathrm{M}$ (Fig. 3B). During $4 \mathrm{~h}$ of tidal emersion no significant changes of median or maximal thiosulfate concentrations or of the percentage of lugworms containing thiosulfate could be observed. In October 1992 and 1993, 58 specimens of Arenicola marina were analyzed, $95 \%$ of which contained thiosulfate at concentrations of 0.4 to $34.7 \mu \mathrm{M}$. As in July, no changes of median concentrations (6.9 to $11.6 \mu \mathrm{M}$ ), maximal concentrations or percentage of thiosulfate-containing lugworms were found. Medians were significantly lower in October than in July (at $t=$ 2 and $3 \mathrm{~h}$ ). Maximal thiosulfate concentrations in the coelomic fluid of lugworms collected in October were 1.5- to 4 -fold lower than of those collected in July (Fig. 3B)

\section{Anaerobic end products in the tissue of Arenicola marina}

The concentrations of succinate (July 1991 and 1992 and October 1992 and 1993), alanopine and strombine (July 1991 and 1992) in the body wall musculature of freshly caught Arenicola marina were determined in order to follow the onset of an anaerobic metabolism. In July median succinate concentrations increased significantly from $0.33 \mu \mathrm{mol} \mathrm{g}^{-1}$ wet wt at the beginning to $0.81 \mu \mathrm{mol} \mathrm{g} \mathrm{g}^{-1}$ wet wt after $2 \mathrm{~h}$ and $0.92 \mu \mathrm{mol} \mathrm{g}^{-1}$ wet wt after $4 \mathrm{~h}$ of emersion (Fig. 3C). 
The concentrations ranged from 0.07 to $1.24 \mu \mathrm{mol} \mathrm{g}^{-1}$ wet wt at $t=0 \mathrm{~h}$, from 0.39 to $1.43 \mu \mathrm{mol} \mathrm{g}^{-1}$ wet wt at $t=2 \mathrm{~h}$ and from 0.23 to $2.75 \mu \mathrm{mol} \mathrm{g}{ }^{-1}$ wet wt at $t=4 \mathrm{~h}$. Similarly, median and maximal succinate concentrations increased in the body wall tissue of lugworms collected in October with the length of tidal emersion (Fig. 3C). The median concentrations were $0.21 \mu \mathrm{mol}$ $\mathrm{g}^{-1}$ wet $\mathrm{wt}$ in the beginning and increased significantly to $0.62 \mu \mathrm{mol} \mathrm{g}{ }^{-1}$ wet wt after $2 \mathrm{~h}$ and to $1.01 \mu \mathrm{mol} \mathrm{g}{ }^{-1}$ wet wt after $4 \mathrm{~h}$ of emersion. The respective concentrations ranged from 0.06 to $0.31 \mu \mathrm{mol} \mathrm{g}^{-1}$ wet wt at $t=$ $0 \mathrm{~h}$, from 0.34 to $1.21 \mu \mathrm{mol} \mathrm{g}{ }^{-1}$ wet wt at $t=2 \mathrm{~h}$ and from 0.72 to $2.02 \mu \mathrm{mol} \mathrm{g}^{-1}$ wet wt at $t=4 \mathrm{~h}$. No significant differences were observed between lugworms collected in July and those collected in October.

Alanopine in the tissue remained constant (at a level of about $1 \mu \mathrm{mol} \mathrm{g} \mathrm{g}^{-1}$ wet wt) during $4 \mathrm{~h}$ of emersion although maximal alanopine concentrations tended to increase in the first $3 \mathrm{~h}$ of emersion (Table 1). The median strombine level increased significantly from $0.66 \mu \mathrm{mol} \mathrm{g}^{-1}$ wet wt at $t=0 \mathrm{~h}$ to $1.53 \mu \mathrm{mol} \mathrm{g}^{-1}$ wet wt after $3 \mathrm{~h}$ of emersion. Similarly, maximal strombine concentrations increased from 1.10 to $6.35 \mu \mathrm{mol} \mathrm{g} \mathrm{g}^{-1}$ wet $w$ t in the same period of time (Table 1). However, median and maximal strombines concentrations decreased to 0.88 and $3.95 \mu \mathrm{mol} \mathrm{g}^{-1}$ wet wt after $4 \mathrm{~h}$ of emersion.
Table 1 Arenicola marina. Alanopine and strombine ( $\mu$ mol $\mathrm{g}^{-1}$ wet $\left.w t\right)$ in the body wall tissue of freshly caught specimens during tidal emersion in July 1991 and 1992. n: number of analyzed lugworms. Maximal and minimal values and medians are given. 'Significant difference of the median of the 2 opines to the median at $t=0$

\begin{tabular}{|crccc|}
\hline $\begin{array}{c}\text { Time of emersion } \\
(\mathrm{h})\end{array}$ & $\mathrm{n}$ & $\begin{array}{c}\text { Min. } \\
\text { value }\end{array}$ & $\begin{array}{c}\text { Max. } \\
\text { value }\end{array}$ & Median \\
\hline Alanopine & & & & \\
0 & 8 & 0.49 & 1.40 & 0.86 \\
1 & 11 & 0.25 & 2.70 & 0.88 \\
2 & 12 & 0.06 & 3.36 & 0.47 \\
3 & 10 & 0.25 & 4.23 & 1.27 \\
4 & 10 & 0.14 & 2.25 & 1.08 \\
Strombine & & & & \\
0 & 8 & 0.22 & 1.10 & 0.66 \\
1 & 11 & 0.13 & 3.74 & 0.93 \\
2 & 12 & 0.09 & 4.13 & 0.91 \\
3 & 10 & 0.30 & 6.35 & 1.53 \\
4 & 10 & 0.10 & 3.95 & 0.88 \\
& & & & \\
\hline
\end{tabular}

\section{Recovery}

Specimens of Arenicola marina were collected after $4 \mathrm{~h}$ of emersion and were incubated in normoxic seawater in order to investigate recovery from tidal exposure. The median sulfide concentration in the coelomic
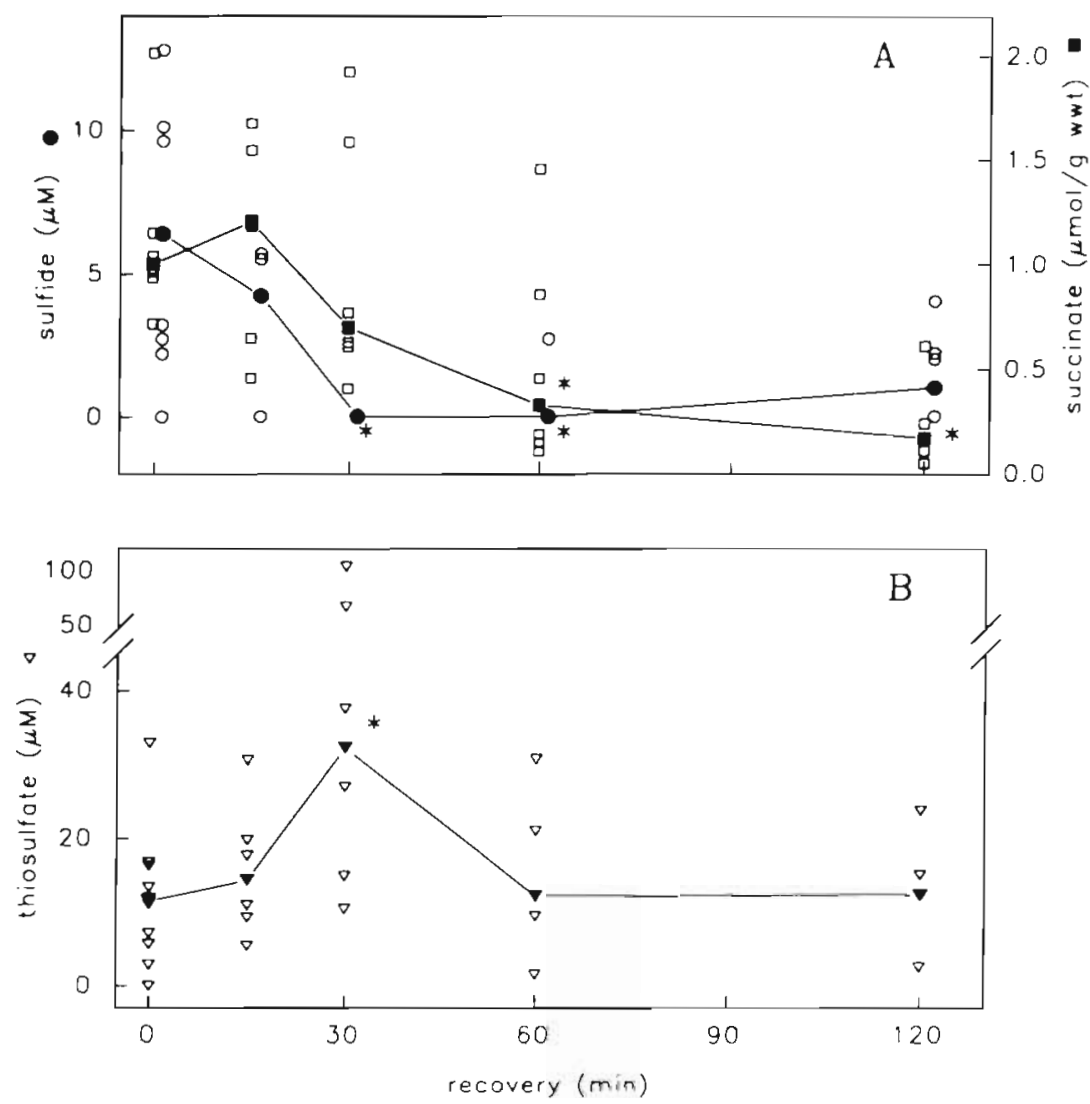

Fig. 4. Arenicola marina. (A) Sulfide in the coelomic fluid $(\mu \mathrm{M} ; \circ)$ and succinate in the body wall tissue ( $\mu$ mol $\mathrm{g}^{-1}$ wet wit; $\left.\square, \boldsymbol{\square}\right)$ and $(B)$ thiosulfate in the coelomic fluid $(\mu \mathrm{M} ; \nabla, \nabla)$ of lugworms collected in October. Lugworms were collected after $4 \mathrm{~h}$ of tidal emersion $(t=0 \mathrm{~min})$ and were allowed to recover in normoxic seawater. Open symbols represent data from individual lugworms; closed symbols are median concentrations. (*) Median concentration is significantly different from the median at $t=0 \mathrm{~min}$. The data for $t=0$ min are identical with $t=4 \mathrm{~h}$ (October) in Fig. 3. For clarity, sulfide data in (A) are shifted to the right. The number of lugworms at $t=0,15,30,60$ and $120 \mathrm{~min}$ of recovery was (with the number of lug. worms containing no sulfide in parentheses): $9(2), 5(2), 6(6), 5(4)$ and $6(3)$. Thiosulfate and succinate were found in all Iugworms $(n=5$ or 6$)$ 
fluid began to decrease from $6.4 \mu \mathrm{M}$ (see above) to $4.2 \mu \mathrm{M}$ after $15 \mathrm{~min}$ of recovery (Fig. 4A). Sulfide was completely removed from the coelomic fluid after $30 \mathrm{~min}$ of recovery. Succinate concentrations were still high after $15 \mathrm{~min}$ of recovery (median $=1.21 \mu_{\mathrm{mol} \mathrm{g}}^{-1}$ wet $w \mathrm{t})$, began to decrease after $30 \mathrm{~min}\left(0.7 \mu \mathrm{mol} \mathrm{g}^{-1}\right.$ wet wt) and reached control values after 60 and $120 \mathrm{~min}$ of recovery (medians $=0.33$ and $0.17 \mu \mathrm{mol} \mathrm{g}^{-1}$ wet $w t$, respectively) (Fig. $4 \mathrm{~A}$ ). In contrast, the median thiosulfate concentration in the coelomic fluid of $A$. marina showed a sudden significant increase from 14.4 to $32.4 \mu \mathrm{M}$ after $30 \mathrm{~min}$ of recovery with concentrations ranging from 10.6 to $103.5 \mu \mathrm{M}$ (Fig, 4B). After $60 \mathrm{~min}$ of recovery, the median thiosulfate concentration had returned to the control value of $12.3 \mu \mathrm{M}$, concentrations ranging from 1.6 to $30.9 \mu \mathrm{M}$.

\section{DISCUSSION}

\section{Environmental sulfide concentrations}

Sulfide was measured in the pore water of the sediment in the vicinity of lugworm burrows in order to see whether sulfide concentrations vary during tidal exposure. Like many other marine sediments (Ott \& Novak 1989) the area exhibited a pronounced heterogeneity (Fig. 1). Maximal sulfide concentrations were comparable to earlier investigations $[250 \mu \mathrm{M}$ in this study as compared to $340 \mu \mathrm{M}$ in Völkel \& Grieshaber (1992) with both values obtained from July measurements]. Sulfide concentrations decreased with depth (Fig. 1): the maximal concentration was only $44 \mu \mathrm{M}$ at a depth of $30 \mathrm{~cm}$, which may be due to a decreasing rate of sulfate reduction parallel to a decreasing sulfate gradient in the sediment (Jørgensen 1977).

Although in some cases pore water sulfide concentrations increased during $4 \mathrm{~h}$ of tidal emersion, variations between different sampling sites were high and no significant changes of sulfide concentrations could be observed.

Sulfide concentrations in the water of lugworm burrows were generally lower than pore water concentrations although sulfide was detected in $42 \%$ of the analyzed burrows. Most of them did not contain any sulfide just after the water had receded. During $4 \mathrm{~h}$ of tidal emersion the percentage of burrows containing sulfide doubled whereas median sulfide concentrations in the burrow rose slightly but not significantly. A significant increase to $14.5 \mu \mathrm{M}$ was only observed after $5 \mathrm{~h}$ of emersion in October (Fig. 2). In July, however, sulfide concentrations up to $30 \mu \mathrm{M}$ could be measured in single burrows over the whole period of emersion. These sporadic high values may be due to sediment heterogeneity as mentioned above. On the other hand, sulfide concentrations in burrow water is frequently higher in summer than in winter and spring (Arp et al. 1989).

Arp et al. (1992) found sulfide in 50 to $70 \%$ of Urechis caupo burrows with maximal concentrations of 25 to $65 \mu \mathrm{M}$ (samples from 2 different sites, respectively). In their study samples were taken about $2 \mathrm{~h}$ after emersion and unfortunately these authors give no sulfide concentrations at the beginning of low tide. Waslenchuk et al (1983) analyzed burrows of Callianassa spp. which were covered with water over the whole sampling period. They found sulfide concentrations of 2.0 to $26 \mu \mathrm{M}$ in the burrow water as opposed to less than $0.1 \mu \mathrm{M}$ in the overlying water and 100 to $1000 \mu \mathrm{M}$ in the pore water. Although the shrimps vigorously flush their burrows, irrigation is not continuous and therefore seems to be insufficient to maintain sulfide-free burrows (Waslenchuk et al. 1983). Arenicola marina also exhibits an intermittent irrigation pattern (Davey et al. 1990). It is, therefore, possible that $A$. marina is occasionally exposed to short-term increases of sulfide concentrations in its burrows during high tide. This may explain why sulfide was already found in some burrows at the beginning of low tide (Fig, 2).

\section{Sulfur compounds in freshly caught Arenicola marina}

Sulfide concentrations in the coelomic fluid of Arenicola marina were measured every hour during $4 \mathrm{~h}$ of tidal emersion in order to see how much sulfide is taken up by the worms under habitat conditions. When the flat fell dry, the percentage of lugworms containing sulfide increased with exposure time, along with both the median and the maximal sulfide concentrations in the coelomic fluid. Due to the high variability between lugworms, the increase of median sulfide concentration was only significant after 2 and $3 \mathrm{~h}$ in July and after $4 \mathrm{~h}$ in October (Fig. 3A). Immediately after the water had receded only low sulfide concentrations $(<10 \mu \mathrm{M})$ were found in a few lugworms whereas no sulfide could be measured in about $70 \%$ of the lugworms. These data indicate that either no sulfide was present in the burrow water of these lugworms or that some sulfide was present but that entering sulfide could be oxidized due to a sufficiently high oxygen supply during high tide. In earlier investigations (Völkel \& Grieshaber 1994) we observed that under normoxic conditions $A$. manina is able to prevent an increase of sulfide in the coelomic fluid up to an external sulfide concentration of at least $330 \mu \mathrm{M}$, since sulfide entering the body is rapidly oxidized to thiosulfate. Fig. 3B shows that thiosulfate concentrations up to $40 \mu \mathrm{M}$ are present immediately after the water has receded, indicating that some sulfide must have been present in the body of these lugworms and that this sul- 
fide had been oxidized during high tide. Oeschger \& Vetter (1992) measured sulfide and thiosulfate in the hemolymph of freshly caught priapulid Halicryptus spinulosus living in anoxic sediments of the Western Baltic. In their study sulfide concentrations of 86 to $445 \mu \mathrm{M}$ were measured whereas thiosulfate amounted to 21 to $84 \mu \mathrm{M}$. These high internal sulfide levels may be a consequence of limited oxygen conditions together with pore water sulfide concentrations up to $665 \mu \mathrm{M}$. (Oeschger \& Vetter 1992).

In the coelomic fluid of Arenicola marina collected in July, sulfide concentrations rose significantly to about $35 \mu \mathrm{M}$ after $3 \mathrm{~h}$ of emersion and maximal concentrations were even higher (Fig. 3A). In the lugworm burrows sulfide levels were 20 to $30 \mu \mathrm{M}$ at most (Fig. 2). Sulfide concentrations within lugworms, therefore, can be higher than burrow water concentrations. In laboratory experiments sulfide concentrations in the coelomic fluid were $60 \mu \mathrm{M}$ after $8 \mathrm{~h}$ of hypoxic ( $\mathrm{P}_{\mathrm{O}_{2}}=3$ torr) sediment-free incubation at an external sulfide level of $200 \mu \mathrm{M}$ (Völkel \& Grieshaber 1992). Internal sulfide concentrations reported by Völkel \& Grieshaber were comparable to those which were found in the present study. Under laboratory conditions, however, sulfide concentrations in the coelomic fluid were much lower than external. sulfide concentrations. This was due to a $\mathrm{pH}$-dependent limited influx of sulfide into the body of A. marina (Groenendaal 1981, Völkel \& Grieshaber 1992). Under field conditions sulfide may have entered the lugworm by it feeding on sulfide-rich sediment.

The increase of sulfide within lugworms during low tide indicates that sulfide oxidation was not possible due to the lack of oxygen. In an earlier investigation (Völkel \& Grieshaber 1994) sulfide oxidation proved to be oxygen dependent. Thiosulfate concentrations in the coelomic fluid of Arenicola marina were only $2 \mu \mathrm{M}$ after hypoxic sulfide incubations at a $\mathrm{P}_{\mathrm{O}_{2}}$ of 0.7 torr as opposed to $4.2 \mathrm{mM}$ at a $\mathrm{P}_{\mathrm{O}_{2}}$ of 130 torr (8 h, external sulfide $550 \mu \mathrm{M}$; Völkel \& Grieshaber 1994). Although thiosulfate concentrations were slightly higher in July than in October, no changes of thiosulfate concentrations were observed during tidal exposure (Fig. 3b). Völkel (1992) demonstrated that during hypoxia thiosulfate disappears very slowly from the coelomic fluid of A. marina, which may explain the constant thiosulfate concentrations during tidal exposure.

\section{Anaerobic metabolites in freshly caught Arenicola marina}

During tidal exposure the stagnant water conditions in lugworm burrows can cause anoxia as well as enhanced sulfide load. Both factors prevent aerobiosis, leading to anaerobic metabolism. In an earlier study we demonstrated the accumulation of the anaerobic metabolites succinate, alanopine and strombine in the body wall tissue of Arenicola marina during sulfide incubations under hypoxic conditions (Völkel \& Grieshaber 1992,1994). In the present investigation tissue concentrations of anaerobic metabolites were measured in order to follow the onset of anaerobic metabolism during tidal exposure. Succinate in the body wall tissue of Arenicola marina collected in October increased significantly from $0.21 \mathrm{\mu mol} \mathrm{g}^{-1}$ wet wt to $1.01 \mu \mathrm{mol} \mathrm{g} \mathrm{g}^{-1}$ wet wt after $4 \mathrm{~h}$ of emersion (Fig. 3C). These data show that anaerobiosis commenced at least after $2 \mathrm{~h}$ of tidal exposure. In laboratory experiments succinate amounted to about $1 \mu \mathrm{mol} \mathrm{g}{ }^{-1}$ wet wt after $8 \mathrm{~h}$ of hypoxia ( $\mathrm{P}_{\mathrm{O}_{2}} 1$ to 2 torr) and to about $2 \mu \mathrm{mol} \mathrm{g} \mathrm{g}^{-1}$ wet wt after $8 \mathrm{~h}$ of hypoxic sulfide incubations (external sulfide 200 and $1000 \mu \mathrm{M}$, respectively) (Volkel \& Grieshaber 1992). The above data correspond well to succinate levels in the body wall tissue of freshly caught $A$. marina found in the present study.

Unfortunately, it is impossible to distinguish between environmental and sulfide-dependent anaerobiosis since we do not know the oxygen and sulfide concentrations in the burrow water of the individual lugworms. Fig. 5 shows that most of the lugworms which contain sulfide exhibit high succinate levels ( 0.9 to $1.2 \mu \mathrm{mol} \mathrm{g}{ }^{-1}$ wet $\mathrm{wt}$ ), as aerobiosis cannot be maintained due to inhibition of the cytochrome c oxidase. In contrast, less succinate $\left(0\right.$ to $0.6 \mu \mathrm{mol} \mathrm{g}^{-1}$ wet wt) was found in most lugworms without sulfide. In many other specimens, however, succinate levels were high although no sulfide could be found in their coelomic fluid. In that case, anaerobiosis was probably caused by anoxia and not by sulfide.

Schottler et al. (1984b) measured $0.14 \mu_{\mathrm{mol} \mathrm{g}}{ }^{-1}$ wet wt succinate in the tissue of Arenicola marina at the beginning of low tide, increasing to 0.25 after $2 \mathrm{~h}$ and to $0.28 \mu \mathrm{mol} \mathrm{g}^{-1}$ wet wt after $4 \mathrm{~h}$ of emersion. In the above study the authors give no sulfide concentrations in the environment or in the lugworms. Possibly, the lower succinate level, as compared to the present study, was a consequence of a lower sulfide stress. Schöttler (1989) demonstrated that the extent of anaerobic metabolism also depends on the season, the locality of the intertidal burrow and the development of gametes. Correspondingly, summer specimens of $A$. marina accumulated significantly more succinate during normoxic sulfide incubations than winter specimens (Völkel \& Grieshaber 1994). In the present study, however, no differences of succinate levels between lugworms collected in July and those collected in October were observed (Fig. 3C) although sulfide exposure was significantly higher in July (Fig. 3A). Sulfide entering the body of $A$. marina may quickly reach a critical level ${ }_{i}$ the cytochrome coxidase is blocked, also 


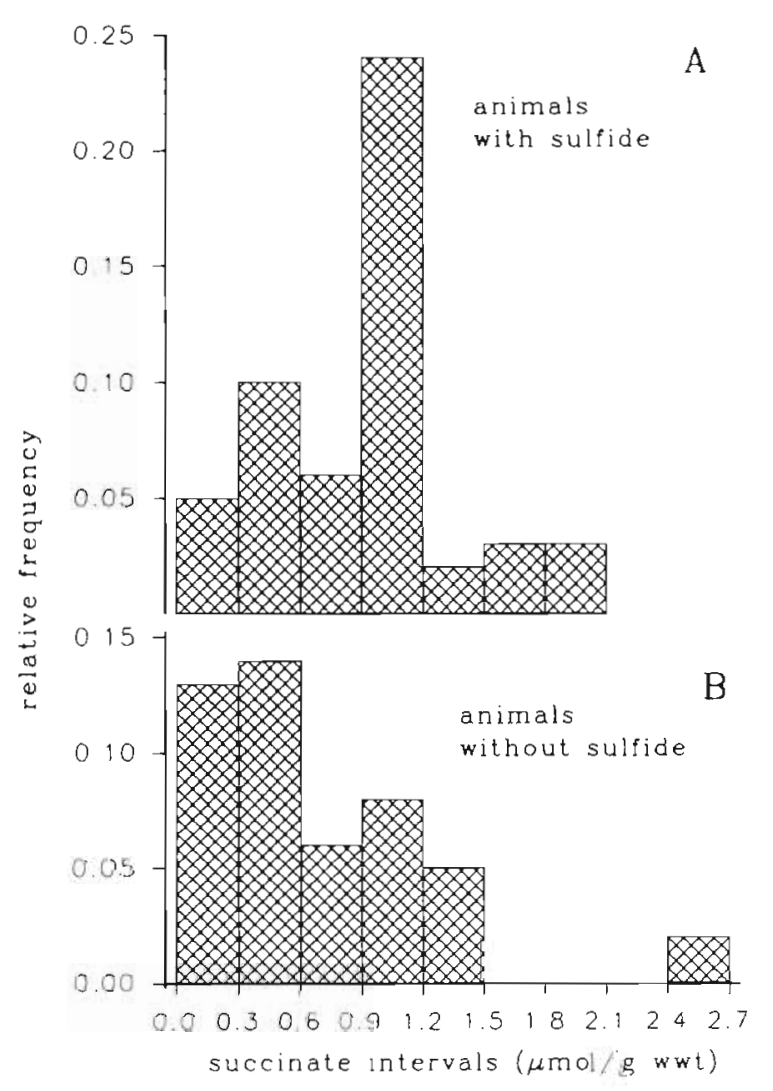

Fig. 5. Arenicola marina. Relative frequency of lugworms plotted against intervals of succinate in the body wall tissue ( $\mu \mathrm{mol} \mathrm{g}^{-1}$ wet wt). Data are obtained from all lugworms (July and October) during the whole period of tidal emersion (see Fig. 3A) for (A) specimens with sulfide and (B) specimens without measurable sulfide in the coelomic fluid

leading to maximal anaerobiosis which does not depend on the sulfide concentration. During hypoxic sulfide incubations there was no difference between succinate accumulation at external sulfide concentrations of 200 or $1000 \mu \mathrm{M}$ (Völkel \& Grieshaber 1992).

In addition to succinate, we measured opine levels in the body wall tissue of lugworms collected in July. Alanopine did not change significantly although maximal concentrations tended to increase in the first $3 \mathrm{~h}$ of emersion (Table 1 ). Strombine concentrations increased significantly during the first $3 \mathrm{~h}$ of tidal exposure. Alanopine and strombine both are glycolytic end products, with alanopine being accumulated preferentially during functional and strombine during environmental anaerobiosis (Siegmund et al. 1985, see also Grieshaber et al. 1992). Strombine therefore accumulates predominantely in Arenicola marina during tidal hypoxia with maximal concentrations being higher than maximal alanopine concentrations. Völkel \& Grieshaber (1992) demonstrated that much more strombine is accumulated during $8 \mathrm{~h}$ of hypoxia, hypoxia plus sulfide, and normoxia plus sulfide as compared to alanopine. Tissue levels of alanopine were about 1 to $1.5 \mu \mathrm{mol} \mathrm{g}{ }^{-1}$ wet wt whereas strombine amounted to $4 \mu \mathrm{mol} \mathrm{g}^{-1}$ wet wt (Völkel \& Grieshaber 1992).

\section{Recovery}

During tidal exposure, sulfide and succinate accumulate in the body of Arenicola marina whereas thiosulfate concentrations remain constant (Fig. 3). As soon as the tide comes back in, the lugworm can irrigate its burrow again. Sulfide which has accumulated in the burrow water is flushed out and the presence of oxygen enables the worm to oxidize sulfide which may have entered its body. When internal sulfide has disappeared, the cytochrome c oxidase is no longer inhibited and $A$. marina is able to switch back to aerobic metabolism. In the present study we mimicked the incoming tide by placing the lugworms into aerated seawater tanks after $4 \mathrm{~h}$ of tidal exposure in the sediment. Sulfide concentrations in the coelomic fluid began to decrease immediately and reached control levels after $30 \mathrm{~min}$ of recovery (Fig. 4A). Two mechanisms may be involved in the disappearance of sulfide: the diffusion into the external medium and the oxidation of sulfide to thiosulfate. The diffusion of sulfide may certainly play a role because biological membranes are permeable to sulfide (Beerman 1924, Julian \& Arp 1992, Völkel \& Grieshaber 1992). On the other hand, Fig. $4 \mathrm{~B}$ shows that thiosulfate in the coelomic fluid of A. marina increases significantly after 30 min of recovery. A rough estimation reveals that sulfide disappears from the coelomic fluid with a rate of $0.12 \mathrm{nmol}$ $\mathrm{min}^{-1} \mathrm{~g}^{-1}$ whereas thiosulfate production is $0.26 \mathrm{nmol}$ $\mathrm{min}^{-1} \mathrm{~g}^{-1}$ (assuming a lugworm weight of about $10 \mathrm{~g}$ and a relative amount of coelomic fluid of $40 \%$ ). One mole of produced thiosulfate is equivalent to 2 moles of oxidized sulfide. Therefore, thiosulfate production during the first $30 \mathrm{~min}$ of recovery must be the consequence of the oxidation of $0.52 \mathrm{nmol} \mathrm{min}{ }^{-1} \mathrm{~g}^{-1}$ sulfide which is 4 -fold higher than the measured rate of sulfide removal. On the other hand, sulfide concentrations in the body wall tissue are much higher as compared to the coelomic fluid. For example, after $7 \mathrm{~h}$ of hypoxic incubations at an external sulfide concentration of $25 \mu \mathrm{M}$, sulfide concentrations increased by about 2 to $3 \mu \mathrm{M}$ in the coelomic fluid and about $30 \mu \mathrm{M}$ in the body wall tissue of $A$. marina (K. Hauschild unpubl. results). Unfortunately, it was not possible to determine tissue sulfide levels because we were not able to determine the fresh weight of the tissue under field conditions. If we assume a similar increase of sulfide in the body wall musculature as seen under experimental conditions, the total removal of sulfide would require a rate

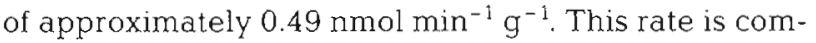


parable to the rate of the actual thiosulfate production. Although the mechanisms of sulfide removal during recovery from sulfide exposure remain to be investigated in detail, it can be assumed that the oxidation of sulfide to thiosulfate plays a major role in this process. After $60 \mathrm{~min}$ of recovery thiosulfate in the coelomic fluid reached the same level as during low tide (Fig. 4B). Very little is presently known about degradation or excretion of thiosulfate. It may be further oxidized to sulfate or it may be excreted via the nephridia. Thiosulfate is not completely removed from the coelomic fluid during $120 \mathrm{~min}$ of recovery. Possibly, any thiosulfate oxidizing or transporting system is only activated by thiosulfate concentrations above a critical threshold.

Parallel to the disappearance of sulfide, the succinate level in the body wall tissue decreases during recovery. Although sulfide had reached control levels after 30 min of recovery, loss of succinate appeared to be slower (Fig. 4A). Pörtner et al. (1979) showed that succinate began to decrease immediately after the onset of aerobic conditions and reached control levels after 1 to $2 \mathrm{~h}$ of recovery from anaerobiosis. From the change of energy status and the immediate cessation of fumarate reduction they concluded that Arenicola marina is able to utilize oxygen as soon as it is available. In the presence of sulfide, however, a rapid onset of aerobiosis is not possible. Fig. 4A shows that considerably high sulfide concentrations are still present after $15 \mathrm{~min}$ of recovery. Correspondingly, the succinate level is still high at this moment. Only when sulfide has disappeared can $A$. marina switch back to an aerobic metabolism, as indicated by decreasing succinate concentrations after $30 \mathrm{~min}$ of recovery (Fig. 4A).

During recovery, thiosulfate concentration in the coelomic fluid of Arenicola marina was maximal after 30 min when sulfide had reached control levels and succinate has decreased (Fig. 4B). Thiosulfate production, however, started earlier when sulfide and succinate levels may still have been high. In an earlier investigation (Völkel \& Grieshaber 1994) we observed an accumulation of thiosulfate in the coelomic fluid of A. marina during normoxic sulfide incubations $\left(\mathrm{P}_{\mathrm{O}_{2}}=130\right.$ torr, external sulfide $1 \mathrm{mM}$ ). In the latter study sulfide was oxidized although internal levels of sulfide and succinate were high.These data indicate that sulfide oxidation in the presence of oxygen is possible even when aerobic metabolism is inhibited by sulfide. Previously we demonstrated that mitochondrial sulfide oxidation in $A$. marina is sulfide insensitive and assumed the existence of an alternative terminal oxidase (Völkel \& Grieshaber 1994). This sulfide detoxification system enables the worm to remove sulfide quickly from its body and to rapidly return to an aerobic metabolism.

\section{Conclusions}

The lugworm Arenicola marina can be exposed to considerably high sulfide concentrations during tidal exposure. Sulfide concentrations can also increase sporadically in some burrows during high tide. Under habitat conditions the lugworm seems to exhibit the same mechanisms of sulfide tolerance as under experimental conditions. In the presence of oxygen, sulfide entering the body of $A$. marina is oxidized to thiosulfate. During high tide, therefore, an increase of sulfide in the body is prevented. Under hypoxic conditions during tidal exposure sulfide cannot be oxidized and sulfide concentrations in the coelomic fluid increase. The accumulation of sulfide together with hypoxia prevent aerobic metabolism and the lugworm switches to anaerobiosis. The lower coelomic $\mathrm{pH}$ as compared to burrow water (B. Giebels unpubl. results) may keep internal sulfide concentrations in some lugworms below the external level. However, coelomic sulfide concentrations increase above external concentrations in many other specimens. When the tide returns and the burrows are immersed sulfide in the body of $A$. marina is rapidly oxidized, which enables the worm to return to aerobic metabolism. After $1 \mathrm{~h}$ of recovery in normoxic seawater sulfide, succinate and thiosulfate have reached the same level as at the beginning of low tide, indicating that 1 high tide is more than sufficient for recovery from sulfide stress during tidal exposure.

Acknowledgements. We thank Silke Jakob for skilful technical assistance. Thanks are also due to our Düsseldorfer collegues for their help in collecting the lugworms. K.H. is a fellow of the Konrad-Adenauer Foundation. Financial support from the Bundesminister für Forschung und Technologie (DYSMON 03F0123B) is also acknowledged

\section{LITERATURE CITED}

Aller RC (1980) Quantifying solute distributions in the bioturbated zone of marine sediments by defining an average micro-environment. Geochim Cosmochim Acta 44 $1955-1965$

Arp AJ, Hansen BM, Julian D (1989) Seasonal sulfide concentrations of the burrow habitat of Urechis caupo: hematin mediated sulfide tolerance in situ. Am Zool 29:69A

Arp AJ, Hansen BM, Julian D (1992) Burrow environment and coelomic fluid characteristics of the echiuran worm Urechis caupo from populations at three sites in northern California. Mar Biol 113:613-623

Bagarinao T (1992) Sulfide as an environmental factor and toxicant: tolerance and adaptations in aquatic organisms. Aquat Toxicol 24:21-62

Beerman H (1924) Some physiological actions of hydrogen sulfide. J exp Zool 41:33-43

Beis J, Newsholm EA (1975) The contents of adenine nucleotides, phosphagens and some glycolytic intermediates in resting muscles from vertebrates and invertebrates. Biochem J 152:23-32 
Beutler HO (1985) Succinat. In: Bergmeyer HU (ed) Methods of enzymatic analysis. Verlag Chemie, Weinheim, p 25-33

Beyer H (1988) U-Test von Wilcoxon, Mann und Whitney ein verteilungsunabhängiges statistisches Verfahren für den Vergleich zweier unabhängiger Stichproben. Z ärztl Fortbild 82:871-873

Brafield AE (1964) The oxygen content of interstitial water in sandy shores. J Anim Ecol 33:97-116

Cline JD, Richards FA (1969) Oxygenation of hydrogen sulfide in seawater at constant salinity, temperature and $\mathrm{pH}$ Environ Sci Technol 3:838-843

Davey JT, Watson PG, Bruce RH, Frickers PE (1990) An instrument for the monitoring and collection of the vented burrow fluids of benthic infauna in sediment microcosms and its application to the polychaetes Hediste diversicolor and Arenicola marina. J exp mar Biol Ecol 139:135-149

De Wit $R$, Jonkers HM, Van den Ende F, Van Gemerden $H$ (1989) In situ fluctuations of oxygen and sulphide in marine microbial sediment ecosystems. Neth $\mathrm{J}$ Sea Res 23:271-281

Fenchel TM, Riedl RJ (1970) The sulfide system: a new biotic community underneath the oxidized layer of marine sand bottoms. Mar Biol 7:255-268

Gilboa-Garber N (1971) Direct spectrophotometric determination of inorganic sulfide in biological materials and in other complex mixtures. Analyt Biochem 43:129-133

Grieshaber MK, Hardewig I, Kreutzer U, Schneider A, Völkel $S$ (1992) Hypoxia and sulfide tolerance in some marine invertebrates. Verh dtsch Zool Ges 85:55-76

Groenendaal M (1979) On sulphide and the distribution of Arenicola marina in a tidal mud flat in the Dutch wadden sea. Neth J Sea Res 13:562-570

Groenendaal M (1980) Tolerance of the lugworm (Arenicola marina) to sulphide. Neth J Sea Res 14:200-207

Groenendaal M (1981) The adaptation of Arenicola marina to sulfide solutions. Neth J Sea Res 15;65-77

Jones JD (1955) Observations on the respiratory physiology and on the haemoglobin of the polychaete genus Nephthys, with special reference to $N$ hombergii. J exp Biol $32: 110-125$

Jorgensen BB (1977) The sulfur cycle of a coastal marine sediment (Limfjorden, Denmark). Limnol Oceanogr 22: $814-832$

Jørgensen BB, Fenchel T (1974) The sulfur cycle of a marine sediment model system. Mar Biol 24:189-201

Julian D, Arp AJ (1992) Sulfide permeability in the marine invertebrate Urechis caupo. J comp Physiol 162B:59-67

Kröger A, Schröder J, Paulsen J, Beilman A (1988) Acetate oxidation with sulphur and sulphate as terminal electron acceptors. In: Cole JA, Ferguson SJ (eds) The nitrogen and sulphur cycles. Cambridge University Press, Cambridge, p $133-145$

Krüger F (1971) Bau und Leben des Wattwurmes Arenicola marina. Helgoländer wiss Meeresunters 22:149-200

Millero FJ (1986) The thermodynamics and kinetics of the hydrogen sulfide system in natural waters. Mar Chem $18: 121-147$

National Research Council (1979) Hydrogen sulfide. University Park Press, Baltimore, p 1-183

Nedwell DB. Floodgate GD (1972) Temperature-induced changes in the formation of sulphide in a marine sediment. Mar Biol 14:18-24

Oeschger R, Vetter RD (1992) Sulfide detoxification and tolerance in Halicryptus spinulosus (Priapulida): a multiple strategy. Mar Ecol Prog Ser 86:167-179
Ott JA, Novak R (1989) Living at an interface: meiofauna at the oxygen/sulfide boundary of marine sediments. In: Ryland JS, Tyler PA (eds) Reproduction, genetics and distributions of marine organisms. 23rd Eur Mar Biol Symp. Olsen \& Olsen, Fredensborg, p 415-422

Pionetti J-M, Toulmond A (1980) Tide-related changes of volatile fatty acids in the blood of the lugworm, Arenicola marina (L.). Can J Zool 58:1723-1727

Pörtner HO, Surholt B, Grieshaber M (1979) Recovery from anaerobiosis of the lugworm Arenicola marina L : changes of metabolite concentrations in the body-wall musculature. J comp Physiol 133:227-231

Schöttler U (1989) Anaerobic metabolism in the lugworm Arenicola marina during low tide: the influence of developing reproductive cells. Comp Biochem Physiol 92A $1-7$

Schöttler U, Wienhausen G, Westermann J (1984a) Anaerobic metabolism in the lugworm Arenicola marina L.: the transition from aerobic to anaerobic metabolism. Comp Biochem Physiol 79B:93-103

Schöttler U, Surholt B, Zebe E (1984b) Anaerobic metabolism in Arenicola marina and Nereis diversicolor during low tide. Mar Biol 81:69-73

Siegmund B, Grieshaber MK, Reitze M, Zebe E (1985) Alanopine and strombine are end products of anaerobic glycolysis in the lugworm Arenicola marina L. Comp Biochem Physiol 82B:337-345

Toulmond A (1973) Tide-related changes of blood respiratory variables in the lugworm, Arenicola marina (L.). Resp Physiol 19:130-144

Toulmond A (1987) Adaptations to extreme hypoxia in water breathers. Comp Physiol environ Adapt 2:123-136

Toulmond $\mathrm{A}$, Tchernigovtzeff $\mathrm{C}$ (1984) Ventilation and respiratory gas exchange of the lugworm Arenicola marina $\mathrm{L}$ as functions of ambient $\mathrm{P}_{\mathrm{O}_{2}}(20-700$ torr). Resp Physiol $57: 349-363$

Vetter RD, Matrai PA, Javor B, O'Brien J (1989) Reduced sulfur compounds in the marine environment: analysis by HPLC. In: Saltzman E, Cooper W (eds) Biogenic sulfur in the environment. American Chemical Society, Symposia Series 393, p 243-261

Vetter RD, Powell MA, Somero GN (1991) Metazoan adaptation to hydrogen sulfide. In: Bryant $C$ (ed) Life without oxygen. Chapman and Hall, London

Vismann B (1991) Sulfide tolerance: physiological mechanisms and ecophysiological implications. Ophelia 34:1-27

Völkel S (1992) Ökophysiologische Untersuchungen über die Sulfidtoleranz des Wattwurmes Arenicola marina L. PhD thesis, Shaker Verlag, Aachen

Völkel S, Grieshaber MK (1992) Mechanisms of sulfide tolerance in the peanut worm Sipunculus nudus (Sipunculida) and in the lugworm Arenicola marina (Polychaeta). J comp Physiol 162B:469-477

Völkel S, Grieshaber MK (1994) Oxygen-dependent sulfide detoxification in the lugworm Arenicola marina. Mar Biol 118:137-147

Waslenchuk DG, Matson EA, Dobbs FC, Tramontano JM (1983) Geochemistry of burrow waters vented by a bioturbating shrimp in bermudian sediments. Mar Biol 72: $219-225$

Watling L (1991) The sedimentary milieu and its consequences for resident organisms. Am Zool 31:789-796

Wollenberger AO, Ristan O, Schoffa G (1960) Eine einfache Technik der extrem schnellen Abkühlung grösserer Gewebestücke. Pflügers Arch 270:399-412 